\title{
CAMELS-BR: hydrometeorological time series and landscape attributes for 897 catchments in Brazil
}

\author{
Vinícius B. P. Chagas ${ }^{1}$, Pedro L. B. Chaffe ${ }^{2}$, Nans Addor ${ }^{3}$, Fernando M. Fan ${ }^{4}$, Ayan S. Fleischmann ${ }^{4}$, \\ Rodrigo C. D. Paiva ${ }^{4}$, and Vinícius A. Siqueira ${ }^{4}$ \\ ${ }^{1}$ Department of Sanitary and Environmental Engineering, Graduate Program of Environmental Engineering, \\ Federal University of Santa Catarina-UFSC, Florianopolis, Brazil \\ ${ }^{2}$ Department of Sanitary and Environmental Engineering, Federal University \\ of Santa Catarina-UFSC, Florianopolis, Brazil \\ ${ }^{3}$ Department of Geography, College of Life and Environmental Sciences, University of Exeter, Exeter, UK \\ ${ }^{4}$ Hydraulic Research Institute, Federal University of Rio Grande do Sul-UFRGS, Porto Alegre, Brazil
}

Correspondence: Pedro L. B. Chaffe (pedro.chaffe@ufsc.br)

Received: 13 March 2020 - Discussion started: 23 April 2020

Revised: 16 July 2020 - Accepted: 25 July 2020 - Published: 8 September 2020

\begin{abstract}
We introduce a new catchment dataset for large-sample hydrological studies in Brazil. This dataset encompasses daily time series of observed streamflow from 3679 gauges, as well as meteorological forcing (precipitation, evapotranspiration, and temperature) for 897 selected catchments. It also includes 65 attributes covering a range of topographic, climatic, hydrologic, land cover, geologic, soil, and human intervention variables, as well as data quality indicators. This paper describes how the hydrometeorological time series and attributes were produced, their primary limitations, and their main spatial features. To facilitate comparisons with catchments from other countries, the data follow the same standards as the previous CAMELS (Catchment Attributes and MEteorology for Large-sample Studies) datasets for the United States, Chile, and Great Britain. CAMELS-BR (Brazil) complements the other CAMELS datasets by providing data for hundreds of catchments in the tropics and the Amazon rainforest. Importantly, precipitation and evapotranspiration uncertainties are assessed using several gridded products, and quantitative estimates of water consumption are provided to characterize human impacts on water resources. By extracting and combining data from these different data products and making CAMELS-BR publicly available, we aim to create new opportunities for hydrological research in Brazil and facilitate the inclusion of Brazilian basins in continental to global large-sample studies. We envision that this dataset will enable the community to gain new insights into the drivers of hydrological behavior, better characterize extreme hydroclimatic events, and explore the impacts of climate change and human activities on water resources in Brazil. The CAMELS-BR dataset is freely available at https://doi.org/10.5281/zenodo.3709337 (Chagas et al., 2020).
\end{abstract}

\section{Introduction}

Large-scale hydrological research relies on data from large samples of catchments to formulate general conclusions on hydrological processes and models (Gupta et al., 2014; Addor et al., 2019). Hydrometeorological datasets with large spatial and temporal coverage are the basis to improve hydrological understanding with appropriate statistical robustness. For example, multiple studies used large-sample datasets to investigate the drivers of hydrological change (e.g., Slater et al., 2015; Blöschl et al., 2019a; Gudmundsson et al., 2019), the impacts of anthropic activities on the water cycle (e.g., Milliman et al., 2008; Hoekstra and Mekonnen, 2012; Montanari et al., 2013), hydrological similarity and classification (e.g., Berghuijs et al., 2014; Sawicz et al., 2014; Knoben et al., 2018), predictions in ungauged basins (e.g., Yadav et al., 2007; Ehret et al., 2014; Singh et al., 2014), areas where ex- 
treme events are a concern (e.g., Van Lanen et al., 2013; Villarini, 2016; Woldemeskel and Sharma, 2016), and the prediction of future hydrological change (e.g., Luke et al., 2017; Zscheischler et al., 2018). Moreover, large-sample hydrology is needed for evaluation of continental to global hydrological models; to identify limitations in model structure, parameterization, and forcing according to geographic and climatic regions (Haddeland et al., 2011; Gudmundsson et al., 2012; Beck et al., 2017a; Zhao et al., 2017; Siqueira et al., 2018; Veldkamp et al., 2018); to estimate uncertainty in model estimates (e.g., Müller Schmied et al., 2014; Beck et al., 2016; Hirpa et al., 2018); and to make use of data assimilation techniques (e.g., Wongchuig et al., 2019). Better predictions in such models allow for the quantification of water resources availability over large scales and are fundamental for nationwide water resources planning and management (Schewe et al., 2014; Bierkens, 2015; Döll et al., 2016; Alfieri et al., 2020).

To uncover the hydrological functioning of a catchment, it is key to understand how it is controlled by climate, human interference (Wohl et al., 2012; Di Baldassarre et al., 2018), and landscape attributes, such as vegetation, topography, soil, and lithology (Fan et al., 2019). For this, researchers must work with a multiple-hypotheses framework (Merz et al., 2012; Pfister and Kirchner, 2017), which frequently leads to processing massive amounts of data and often tedious, repetitive tasks. To deal with this problem, multiple datasets have been created, such as the Global Runoff Data Center (GRDC, 2019), the Global Streamflow Indices and Metadata Archive (GSIM; Do et al., 2018; Gudmundsson et al., 2018), the HydroATLAS (Linke et al., 2019), and the Global Runoff Reconstruction (GRUN; Ghiggi et al., 2019). A noteworthy dataset, the Catchment Attributes and MEteorology for Large-sample Studies (CAMELS; Newman et al., 2015; Addor et al., 2017), produced a synthesis from multiple catchment attributes. It initially only included catchments in the United States but later expanded to include Chile with the CAMELS-CL dataset (Alvarez-Garreton et al., 2018) and Great Britain with CAMELS-GB (Coxon et al., 2020). The CAMELS datasets facilitated hydrological research by addressing some of the major problems with large datasets, such as a lack of common standards across databases, absence of uncertainty estimation, and open accessibility of hydrological observations (Addor et al., 2019).

Even though there is a growing number of large-sample datasets worldwide (e.g., Addor et al., 2017; Do et al., 2018; Gudmundsson et al., 2018; Ghiggi et al., 2019; Linke et al., 2019), the access to open and readily available data in some regions like South America is still difficult and requires additional quality checks (Crochemore et al., 2019). Particularly in Brazil, large-sample hydrological studies lack a comprehensive dataset to rely on. Brazilian hydrometeorological information is currently collected, maintained, and distributed by institutions such as the Brazilian National Water Agency (ANA - Agência Nacional de Águas; http: //www.snirh.gov.br/hidroweb/, last access: 15 August 2020) and the National Institute of Meteorology (INMET; https: //portal.inmet.gov.br/, last access: 15 August 2020). The creation of ANA in 2000 led to the release of open hydrological information, which prompted the growth of hydrological studies and fostered water resources management. However, the use of data provided for Brazilian catchments is challenging because (i) it requires either manual data acquisition of one station at a time through the institutions' local repositories (e.g., ANA, 2019a) or web-scraping techniques to access these data in an automated fashion; (ii) there is little consistency in data format across regions and stations; and (iii) current datasets do not systematically provide catchment attributes characterizing the hydroclimate, landscape, and anthropogenic influences. Further, the difficulty of accessing national meteorological daily time series has led users to compute them from other gridded global databases (e.g., Xavier et al., 2016; Beck et al., 2017c; Sun et al., 2018). All these difficulties hinder large-sample hydrological studies in Brazil where, unsurprisingly, nationwide studies (e.g., Siqueira et al., 2018; Bartiko et al., 2019) are less common than in North America or Europe. Consequently, studies in Brazil generally include only a reduced number of stream gauges and catchment attributes and are restricted to specific regions, such as the Amazon (e.g., Tomasella et al., 2011; Paiva et al., 2013; Latrubesse et al., 2017; Levy et al., 2018) or the La Plata basin (e.g., Collischonn et al., 2001; Pasquini and Depetris, 2007; Melo et al., 2016; Lima et al., 2017; Chagas and Chaffe, 2018).

To overcome these limitations, we produced and made publicly available a new dataset for large-sample hydrological studies in Brazil, CAMELS-BR. It includes daily streamflow time series from 3679 stream gauges and, for a selected group of 897 catchments, daily meteorological time series and 65 catchment attributes from properties such as topography, climate, land cover, geology, soil, and human intervention. All catchment attributes and time series are in an easily readable file format and on a quickly accessible database. We follow standards defined by the previous CAMELS and CAMELS-CL datasets, thus allowing direct comparisons with them. Most attributes rely on data products that cover the whole of South America, so they are spatially consistent across Brazil. To reduce the risk of data misinterpretation, we describe the major limitations of the data sources and indices computed. By synthesizing hydrological information from thousands of catchments in Brazil into a single dataset, we allow researchers to skip the arduous task of collecting and preprocessing large quantities of disparate data. 


\section{Hydrometeorological daily time series}

\subsection{Streamflow data}

We provide daily streamflow time series for two sets of gauges (Table 1). The first set comprises 3679 streamflow gauges and is provided by the Brazilian National Water Agency (ANA, 2019a). We refer to these as "raw streamflow" time series, as they are readily available from ANA (2019a). Their values are unchanged but, to ease their processing, we converted the native files (i.e., Excel files with daily streamflows not disposed in chronological order) to a new file format (i.e., text files with daily streamflow in chronological order). ANA estimates daily streamflow either by (i) taking two daily stream stage measurements, one in the morning (at 07:00 LT, local time) and another in the afternoon (at 17:00 LT), which are averaged and transformed into discharge using a stage-discharge relationship (rating curve), or (ii) resorting to regionalization methods when no stream stage measurements are available (no further details on the methods are provided by ANA). The raw streamflow time series cover different periods, ranging from a few days to more than a century. Additionally, although ANA performs data quality checks, these time series include inconsistencies, such as typographical errors and days with missing data. The 3679 gauges are irregularly distributed throughout the country (Fig. 1a). Overall, their spatial distribution is denser and their time series longer in the southern Atlantic, southeastern Atlantic, and Paraná hydrographic regions (Fig. 1a and b).

The second set of streamflow time series includes 897 gauges, and here we simply refer to them as "streamflow" time series (Table 1). This is the set of gauges used to compute the catchment attributes. It is a subset from the previous 3679 gauges, which resulted from two selection criteria. Firstly, we selected only gauges that have less than $5 \%$ of missing streamflow data between the water years 1990 (starting on 1 September 1989) and 2009 (ending on 31 August 2009). We chose the water years from 1990 to 2009 because (i) it is the period with the largest number of stream gauges with available data (Fig. 2) and (ii) it coincides with the period of analysis from other CAMELS datasets (Addor et al., 2017; Alvarez-Garreton et al., 2018), allowing for direct comparisons with them. Secondly, we only considered catchments for which boundaries have been delimited by Do et al. (2018) and for which there is a good match with the area estimated by the data provider (see Sect. 3). Although the hydrological signatures introduced below were computed using data from 1990 to 2009, the time series for the 897 stream gauges include data from 1980 to 2018 when available, to enable complementary analyses by other users.

We individually screened the 897 selected streamflow time series between 1990 and 2009 for the following errors: zeroes or repeated values instead of missing values, abrupt changes resulting from changes in measurement instruments or rating curves, annual streamflow larger than annual precipita- tion, and unrealistic daily streamflow values (i.e., larger than $1000 \mathrm{~mm} \mathrm{~d}^{-1}$ ). Gauges affected by such errors were not included in the set of 897 catchments. In addition, we summarized the streamflow metadata provided by ANA as follows. For each daily streamflow measurement, we provide two pieces of information (Table 1). The first metadata variable, "qual_control_by_ana", was set to 1 if the data was quality checked by ANA and to 0 otherwise. The second metadata variable, "qual_flag", indicates the reliability of streamflow estimates. It is also provided by ANA and consists of the following quality flags: 0 , when there is no description; 1 , streamflow resulted from stream stage measurements and the rating curve; 2, streamflow estimated by ANA without stream stage measurements; 3 , streamflow values marked as doubtful; and 4, when the stream water level falls outside the range of the stream stage, e.g., when the river ran dry. To summarize the ANA metadata (i.e., q_qual_control_perc and q_stream_stage_perc; Table 2), $80 \%$ of the 897 gauges had at least $90 \%$ of their data over 1990-2009 checked for inconsistencies (Fig. 1c). The Amazon, São Francisco, and Paraná regions have the lowest frequency of quality controls in Brazil. Furthermore, the streamflow estimates from $64 \%$ of the 897 catchments were derived from stream stage measurements for $90 \%$ of the days over 1990-2009 (Fig. 1d).

\subsection{Meteorological data}

Meteorological daily time series data are provided for 897 catchments (Table 1). These include (i) precipitation from CHIRPS v2.0 (Funk et al., 2015), CPC (NOAA, 2019a), and MSWEP v2.2 (Beck et al., 2019); (ii) potential evapotranspiration from GLEAM v3.3a (Miralles et al., 2011; Martens et al., 2017); (iii) actual evapotranspiration from GLEAM v3.3a and MGB South America (Siqueira et al., 2018); and (iv) minimum, maximum, and average temperature from CPC (NOAA, 2019b). The datasets were selected because of their high spatial resolution, their full coverage of South America allowing for consistency through all catchments, and because they are commonly used, which enables comparisons with other studies. The daily values represent the average of all cells with their centroids intersected by the catchment, of which all cells contribute to the average equally, whether the catchment fully covers them or not. However, some catchments do not intersect the centroid of any cell. For those, we computed the daily values as the average of all cells partially covered by the catchment. A significant limitation of the meteorological data is that, because the cell grids of the adopted products have resolutions that range from $0.05^{\circ}$ (ca. $5.5 \mathrm{~km}^{2}$ at the Equator) to $0.5^{\circ}$ (ca. $55 \mathrm{~km}^{2}$ at the Equator), some catchments are smaller than a single cell. This leads to the assumption that such a meteorological variable is homogeneous in catchments smaller than a single cell, even though this might not always be the case. This limitation has to be kept in mind particularly when using the CPC precipitation data (resolution of $0.5^{\circ}$; NOAA, 2019), as precipitation is the 
Table 1. Summary of the data provided by CAMELS-BR.

\begin{tabular}{|c|c|c|c|}
\hline & Variable & Description & $\begin{array}{r}\text { No. of } \\
\text { catchments }\end{array}$ \\
\hline \multirow[t]{6}{*}{ Daily time series } & Raw streamflow & $\begin{array}{l}\text { As read from the Brazilian National Water Agency }{ }^{\mathrm{a}} \text { (in } \\
\mathrm{m}^{3} \mathrm{~s}^{-1} \text { ) with varying coverage periods and data quality } \\
\text { flags (qual_control_by_ana and qual_flag) for each time } \\
\text { step }\end{array}$ & 3679 \\
\hline & Streamflow & $\begin{array}{l}\text { Covering from 1980-2018 (transformed to } \mathrm{mm} \mathrm{d}^{-1} \text { ), with } \\
\text { data quality flags (qual_control_by_ana and qual_flag) for } \\
\text { each time step }\end{array}$ & 897 \\
\hline & Precipitation & $\begin{array}{l}\text { Catchment averages }\left(\mathrm{mm} \mathrm{d}^{-1}\right) \text { using three products: } \\
\text { CHIRPS v2.0 }\left(0.05^{\circ} \text { res., covering from } 1981-2018\right)^{\mathrm{b}}, \text { CPC } \\
\text { Global Unified }\left(0.5^{\circ} \text { res., } 1980-2018\right)^{\mathrm{c}} \text {, and MSWEP v2.2 } \\
\left(0.1^{\circ} \text { res., } 1980-2016\right)^{\mathrm{d}} \text {. }\end{array}$ & 897 \\
\hline & Potential evapotranspiration & $\begin{array}{l}\text { Catchment averages }\left(\mathrm{mm} \mathrm{d}^{-1}\right) \text { using GLEAM v3.3a }\left(0.25^{\circ}\right. \\
\text { res., } 1980-2018)^{\mathrm{e}}\end{array}$ & 897 \\
\hline & Actual evapotranspiration & $\begin{array}{l}\text { Catchment averages }\left(\mathrm{mm} \mathrm{d}^{-1}\right) \text { using two products: } \\
\text { GLEAM v3.3a }\left(0.25^{\circ} \text { res., } 1980-2018\right)^{\mathrm{e}} \text { and MGB }\left(0.5^{\circ}\right. \\
\text { res., } 1980-2014)^{\mathrm{f}}\end{array}$ & 897 \\
\hline & $\begin{array}{l}\text { Minimum, maximum, and } \\
\text { average temperature }\end{array}$ & $\begin{array}{l}\text { Catchment averages }\left({ }^{\circ} \mathrm{C} \mathrm{d}^{-1}\right) \text { using CPC Global Unified } \\
\left(0.5^{\circ} \text { res., } 1980-2018\right)^{\mathrm{g}}\end{array}$ & 897 \\
\hline \multirow[t]{9}{*}{ Catchment attributes } & Location & 5 attributes (Table 2) & 3679 \\
\hline & Topography & 4 attributes (Table 2) & 897 \\
\hline & Data quality checks & 2 attributes (Table 2) & 897 \\
\hline & Climatic indices & 13 attributes (Table 3 ) & 897 \\
\hline & Hydrological signatures & 13 attributes (Table 4) & 897 \\
\hline & Land cover characteristics & 11 attributes (Table 5) & 897 \\
\hline & Geologic characteristics & 7 attributes (Table 6) & 897 \\
\hline & Soil characteristics & 6 attributes (Table 7) & 897 \\
\hline & Human intervention indices & 4 attributes (Table 8 ) & 897 \\
\hline
\end{tabular}

${ }^{\mathrm{a}}$ ANA (2019a). ${ }^{\mathrm{b}}$ Climate Hazards Group InfraRed Precipitation with Station data v2.0 (Funk et al., 2015). ${ }^{\mathrm{c}}$ Climate Prediction Center Global Unified Gauge-Based Analysis of Daily Precipitation (NOAA, 2019a). ${ }^{\mathrm{d}}$ Multi-Source Weighted-Ensemble Precipitation (Beck et al., 2019). ${ }^{\mathrm{e}}$ Global Land Evaporation Amsterdam Model v3.3a (Miralles et al., 2011; Martens et al., 2017). ${ }^{\mathrm{f}}$ Large-Scale Hydrological Model (Siqueira et al., 2018). ${ }^{\mathrm{g}}$ Climate Prediction Center Global Daily Temperature (NOAA, 2019b).

Table 2. Location, topographic characteristics, and data quality checks.

\begin{tabular}{llll}
\hline Attribute & Description & Units & Data source \\
\hline gauge_id & Catchment identifier provided by ANA & - & ANA (2019a) \\
gauge_name & Gauge name provided by ANA & - & ANA (2019a) \\
gauge_region & Hydrographic region & - & ANA (2019a) \\
gauge_lat & Gauge latitude & ${ }^{\circ} \mathrm{N}$ & ANA (2019a) \\
gauge_lon & Gauge longitude & ${ }^{\circ} \mathrm{E}$ & ANA (2019a) \\
elev_gauge & Gauge elevation & m a.s.l. & HydroSHEDS 15 arcsec DEM \\
elev_mean & Catchment mean elevation & m a.s.l. & HydroSHEDS 15 arcsec DEM \\
slope_mean & Catchment mean slope & $\mathrm{m} \mathrm{km}^{-1}$ HydroSHEDS 15 arcsec DEM \\
area & Catchment area & $\mathrm{km}^{2}$ & Do et al. (2018) \\
q_quality_control_perc & Percentage of streamflow data (1990-2009) with quality control & $\%$ & ANA (2019a) \\
& checks by ANA & & ANA (2019a) \\
q_stream_stage_perc & Percentage of streamflow data (1990-2009) derived from & $\%$ & A \\
& stream stage measurements & & \\
\hline
\end{tabular}




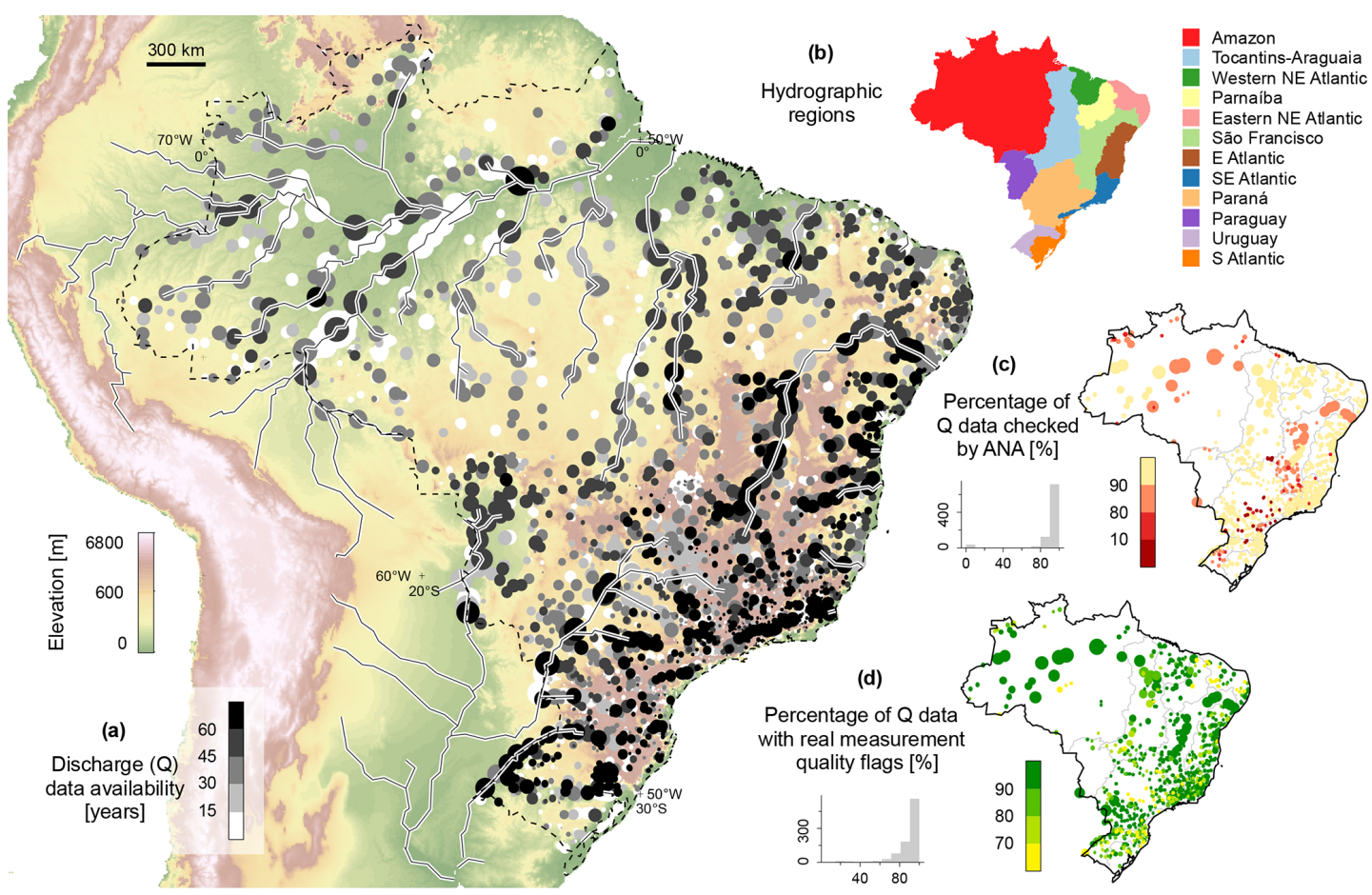

Figure 1. (a) South America and the total river discharge data availability of the 3679 stream gauges included in this study. The black line surrounded by a white line indicates rivers. The dashed line is Brazil's borders. (b) Hydrographic regions of Brazil according to ANA (2019a). (c) Percentage of streamflow data with quality control checks by ANA of the 897 selected catchments. (d) Percentage of streamflow data derived from stream stage measurements of the 897 selected catchments. The circles are located at the outlet of the catchments and their sizes are proportional to the sizes of the catchments. The grey line in (c) and (d) indicates the limits of hydrographic regions.

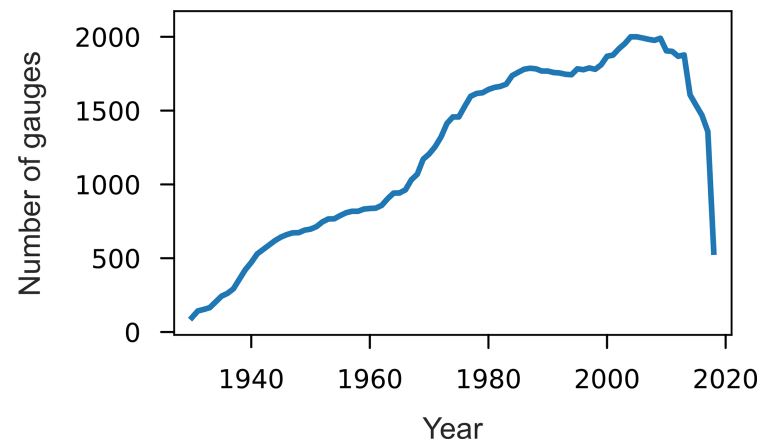

Figure 2. Time series with the number of streamflow gauges with at least one measurement for a given year in Brazil.

meteorological variable with the highest spatial heterogeneity amongst those used in CAMELS-BR.

In addition to GLEAM v3.3a, estimates of actual evapotranspiration (ET) were obtained from the MGB model version for South America (Siqueira et al., 2018). The MGB is a conceptual, semi-distributed hydrologic-hydrodynamic model that discretizes the basin (or a set of basins) into irregular unit catchments and further into hydrological response units by combinations of land use and soil types, where both water and energy balance are computed. The model cal- culates ET using the Penman-Monteith equation based on CRU meteorological data (i.e., temperature, pressure, radiation, and wind speed) and MSWEP v1.1 precipitation data (Beck et al., 2017b). Surface resistance is adjusted according to the availability of water in the soil that is updated during the water budget. The MGB also computes the evaporation of flooded areas and intercepted water from the canopy with the Penman equation. Regular ET cells of $0.5^{\circ}$ resolution were generated by aggregating unit catchments using their areas as weights.

The long-term water balance is accurate for most catchments, using either the estimated evapotranspiration from GLEAM (Fig. 3a) or MGB (Fig. 3b). Both evapotranspiration data sources indicate that the highest data uncertainties occur in the Amazon and smaller catchments in the Paraná and the southeastern Atlantic regions since those catchments are further away from the $1: 1$ line in Fig. 3a-b. The same conclusions are derived from visualizing the runoff coefficient as a function of the humidity index (Fig. 3c). In addition, there are remarkable differences between GLEAM and MGB estimates, where evapotranspiration from GLEAM is substantially higher in the Amazon basin and substantially lower in the eastern and the western Northeast Atlantic regions. 

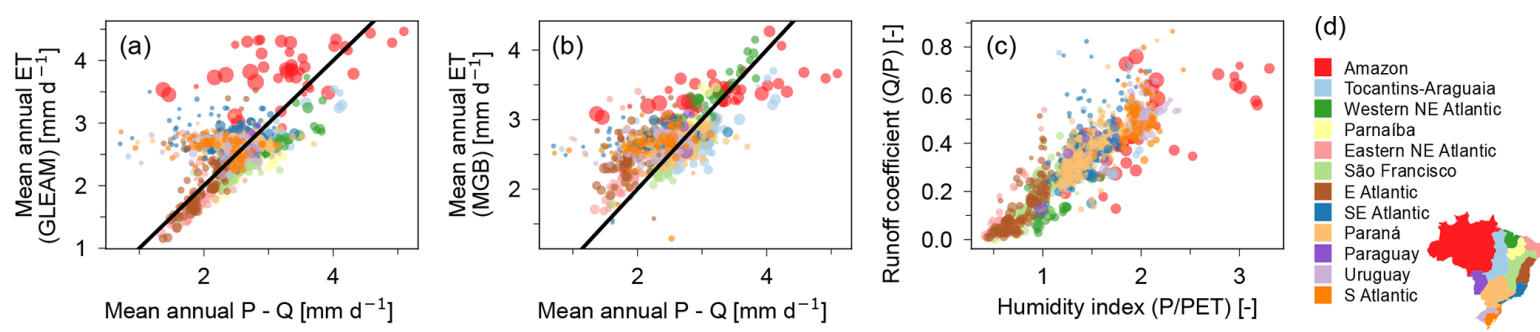

Figure 3. Long-term water balance of the 897 selected catchments for the water years 1990-2009. Mean annual evapotranspiration from (a) GLEAM or (b) MGB as a function of the difference between mean annual precipitation $(P)$ from CHIRPS and streamflow $(Q)$. (c) Runoff coefficient as a function of the humidity index. Line $1: 1$ is shown in black. The symbol size is proportional to the catchment area. The symbol color indicates the hydrographic region of the catchment (from panel d).

\section{Topographic indices}

Even though ANA (2019a) provides estimates of the areas of most gauged Brazilian catchments, the catchment boundaries are not publicly available. Hence, in this study, we used the catchment boundaries provided by Do et al. (2018), who used the HydroSHEDS 15 arcsec resolution digital elevation model (DEM) and delineated the catchments with a procedure similar to Lehner (2012) for more than 3000 gauges in Brazil. For each streamflow gauge, Do et al. (2018) positioned the outlet at the center of all the DEM grid cells within a radius of $5 \mathrm{~km}$ from the gauge coordinates indicated by the metadata. They then selected the grid cell (and associated catchment boundaries) leading to the catchment area most similar to the one indicated by ANA (2019a). The main limitation of the procedure of Do et al. (2018) is that catchment boundaries were not manually inspected.

Using those catchment boundaries, we computed four topographic attributes (Table 2), namely gauge elevation, catchment mean elevation, mean slope, and area. The area of the catchments ranged from $10.8 \mathrm{~km}^{2}$ (i.e., in the upper São Francisco hydrographic region) to 4.7 million square kilometers (i.e., the Amazon basin at Óbidos). Approximately $30 \%$ of the analyzed catchments are smaller than $1000 \mathrm{~km}^{2}, 43 \%$ are between 1000 and $10000 \mathrm{~km}^{2}$, and $27 \%$ are larger than $10000 \mathrm{~km}^{2}$. The largest basins are in the Amazon and the Tocantins-Araguaia hydrographic regions (Fig. 4a). Combined with the Paraguay basin, those regions are usually characterized by low elevations (Fig. 4b), flat slopes (Fig. 4c), and large proportions of wetlands (see Sect. 6.2). The smaller catchments are located along the mountain belts on the eastern coast of Brazil, particularly in the southern and southeastern parts of the country. Those are also the catchments with the steepest slopes. Additionally, many catchments with intermediate elevation ranges (i.e., between 500 and $900 \mathrm{~m}$ ) are in the central part of the country, which comprises the Brazilian highlands. Note that since we computed the average attribute value (unless otherwise noted) of each catchment, the attributes become less representative as the area of the catchment increases.

\section{Climatic indices}

\subsection{Data and methods}

We computed 13 climatic indices (Table 3 ) over the same period (1990 to 2009, except for the asynchronicity index) as the ones in CAMELS (Addor et al., 2017) and CAMELS-CL (Alvarez-Garreton et al., 2018). The first water year starts on 1 September 1989 and the last one finishes on $31 \mathrm{Au}-$ gust 2009. This is to facilitate inter-dataset comparability. We used precipitation data from CHIRPS v2.0 (Funk et al., 2015) to compute the indices since it has the highest spatial resolution among the three adopted precipitation products (i.e., CHIRPS v2.0, CPC, and MSWEP v2.2) and relies on both remote sensing and gauge-based data.

The mean precipitation, mean potential evapotranspiration, and the aridity index are considered to capture longterm climatic conditions. The aridity index is the ratio of mean potential evapotranspiration to mean precipitation, which stands as a first-order control on the partitioning of precipitation into streamflow (Budyko, 1974; Blöschl et al., 2013). Those indices are complemented by the precipitation seasonality index (p_seasonality, Table 3), which relies on sine curves to approximate the monthly climatology of temperature and precipitation. While, for Brazil the annual precipitation cycle is captured quite well, a sine curve provides a relatively rough approximation of the temperature cycle, particularly in the center of the country (around the state of Goiás; Berghuijs and Woods, 2016). Hence, in addition to p_seasonality, we extracted the asynchronicity index proposed by Feng et al. (2019), which relies on information theory and has the advantage of being nonparametric (in particular, it does not assume sinusoidality). The indices of extreme climatic conditions include the frequency, duration, and the most common season of high-precipitation events and dry days. Dry days are defined as days with precipitation less than $1 \mathrm{~mm}$ so that the index is not compromised by underdetected precipitation events (Haylock and Nicholls, 2000). 


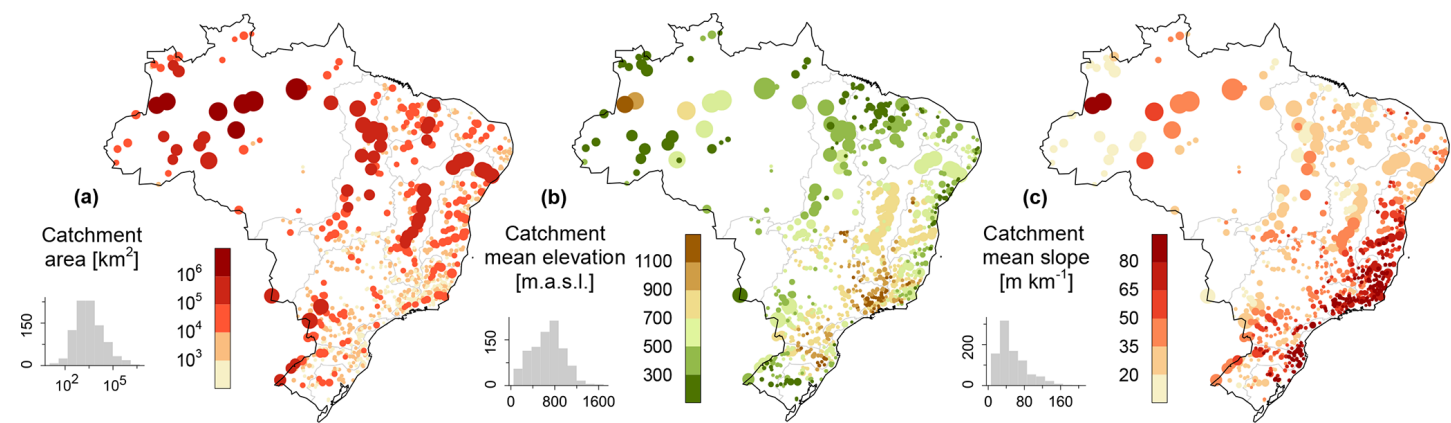

Figure 4. Topographic characteristics of the 897 selected catchments. The size of the circles is proportional to the size of the catchment. The grey line indicates the limits of hydrographic regions.

Table 3. Climatic indices.

\begin{tabular}{|c|c|c|c|}
\hline Attribute & Description & Units & Data source \\
\hline p_mean & Mean daily precipitation & $\mathrm{mm} \mathrm{d}^{-1}$ & CHIRPS v2.0 \\
\hline pet_mean & Mean daily potential evapotranspiration (PET) & $\mathrm{mm} \mathrm{d}^{-1}$ & GLEAM v3.3a \\
\hline et_mean & Mean daily actual evapotranspiration & $\mathrm{mm} \mathrm{d}^{-1}$ & GLEAM v3.3a \\
\hline aridity & $\begin{array}{l}\text { Aridity, computed as the ratio of mean PET to mean precipita- } \\
\text { tion }\end{array}$ & - & GLEAM v3.3a and CHIRPS v2.0 \\
\hline p_seasonality & $\begin{array}{l}\text { Seasonality and timing of precipitation (estimated using sine } \\
\text { curves to represent the annual temperature and precipitation cy- } \\
\text { cles; values are typically between }-1 \text { (precipitation out of phase } \\
\text { with temperature) and } 1 \text { (precipitation in phase with tempera- } \\
\text { ture, i.e., simultaneous peaks); values close to } 0 \text { indicate uni- } \\
\text { form precipitation throughout the year). See Eq. (14) in Woods } \\
(2009) \text {. }\end{array}$ & - & CHIRPS v2.0 \\
\hline asynchronicity & $\begin{array}{l}\text { Asynchronicity between the annual precipitation and PET cy- } \\
\text { cles, where high values represent high relative magnitude and } \\
\text { phase differences }\end{array}$ & - & Feng et al. (2019) \\
\hline frac_snow & $\begin{array}{l}\text { Fraction of precipitation falling as snow (i.e., on days colder } \\
\text { than } 0^{\circ} \mathrm{C} \text { ) }\end{array}$ & - & CHIRPS v2.0 and CPC \\
\hline high_prec_freq & $\begin{array}{l}\text { Frequency of high precipitation days ( } \geq 5 \text { times the mean daily } \\
\text { precipitation) }\end{array}$ & days $\mathrm{yr}^{-1}$ & CHIRPS v2.0 \\
\hline high_prec_dur & $\begin{array}{l}\text { Average duration of high precipitation events (number of con- } \\
\text { secutive days } \geq 5 \text { times the mean daily precipitation) }\end{array}$ & days & CHIRPS v2.0 \\
\hline high_prec_timing & $\begin{array}{l}\text { Season during which most high precipitation days ( } \geq 5 \text { times } \\
\text { the mean daily precipitation) occur }\end{array}$ & season & CHIRPS v2.0 \\
\hline low_prec_freq & Frequency of dry days $\left(<1 \mathrm{~mm} \mathrm{~d}^{-1}\right)$ & days $\mathrm{yr}^{-1}$ & CHIRPS v2.0 \\
\hline low_prec_dur & $\begin{array}{l}\text { Average duration of dry periods (number of consecutive days } \\
<1 \mathrm{~mm} \mathrm{~d}^{-1} \text { ) }\end{array}$ & days & CHIRPS v2.0 \\
\hline low_prec_timing & Season during which most dry days $\left(<1 \mathrm{~mm} \mathrm{~d}^{-1}\right)$ occur & season & CHIRPS v2.0 \\
\hline
\end{tabular}

\subsection{Spatial variability in climatic indices}

The mean daily precipitation in Brazil is highest in the Amazon and in southern Brazil, where it on average exceeds $5 \mathrm{~mm} \mathrm{~d}^{-1}\left(1825 \mathrm{~mm} \mathrm{yr}^{-1}\right)$ (Fig. 5a). The lowest mean precipitation occurs in northeastern Brazil, which is also where mean potential evapotranspiration exceeds the mean precipitation (aridity index $>1$, Fig. 5b). Northeastern Brazil (in particular, the states of Maranhão, Piauí, and Ceará) also has the highest values of asynchronicity index in the country (not shown), which corresponds to Mediterranean climates. The precipitation regime is highly seasonal in most of the country, particularly in the central-west and southeastern Brazil (Fig. 5c). This seasonality is regulated by the South American Monsoon System (Raia and Cavalcanti, 2008; Carvalho et al., 2011), with peaks in the austral summer (Fig. 5f) and several dry months during the austral winter (Fig. 5i). Southern Brazil has a distinct regime, with uniform precipitation throughout the year caused by a combination of large-scale phenomena and a diversity of sources of atmospheric mois- 
ture (Seager et al., 2010; Martinez and Dominguez, 2014). The Amazon basin, which extends into both hemispheres, has contrasting precipitation regimes between the north (with a peak in austral winter) and the south (with a peak in austral summer) related to alternating warming of each hemisphere (Marengo and Espinoza, 2016). This seasonality is substantially diminished downstream in the Amazon.

The number of high-precipitation and dry days is highest along the catchments on the coast (Fig. 5d and g), which is also where the smallest catchments are located. Both indices are significantly correlated with catchment area ( $p$ value $<0.001$ ), so a regional analysis of both indices should be carried out with caution since large catchments are located in the Amazon and Tocantins-Araguaia basins. On the other hand, the duration of high-precipitation (Fig. 5e) and dryday events (Fig. 5h) do not correlate with catchment area. Their spatial distribution is remarkably similar to the aridity index, except for the Tocantins-Araguaia basin, which has long dry periods but not necessarily long high-precipitation events. Summer is the most common season of extreme precipitation in the majority of Brazil, with two main exceptions (Fig. 5f): (i) part of the coast of northern Brazil and (ii) southern Brazil. This is possibly linked to mesoscale convective systems over southeastern South America (Salio et al., 2007), to sea surface temperature anomalies in the Atlantic Ocean (Liebman et al., 2010), and the El Niño-Southern Oscillation phenomenon, as those regions are particularly affected by it (Grimm, 2011; Tedeschi et al., 2013).

\section{Hydrological signatures}

\subsection{Data and methods}

We computed 13 hydrological signatures (Table 4) that represent a wide range of hydrological information for the water years from 1990 to 2009. The hydrological signatures were computed in the same approach as in the CAMELS, CAMEL-CL, and CAMELS-GB datasets. Intermediate streamflow conditions were evaluated with the mean daily flow and its ratio to mean daily precipitation. These were complemented by baseflow information, a fundamental component that sustains streamflow during dry periods (Smakhtin, 2001). The baseflow index is the ratio of longterm baseflow to long-term total streamflow. We used the digital filter from Ladson et al. (2013) to separate the baseflow component from the hydrograph. The variability of streamflow was evaluated with the slope of the flow duration curve and the streamflow elasticity indices. The slope of the flow duration curve is defined as the slope between the log-transformed 33rd and 66th long-term percentiles of daily streamflow (Yadav et al., 2007; Sawicz et al., 2011). High values of that index suggest highly variable streamflow, caused either by a high seasonality of streamflow or by a flashy response to precipitation events (Yokoo and Sivapalan, 2011; McMillan et al., 2017). Streamflow elasticity is an indicator of the sensitivity of mean annual flow to changes in mean annual precipitation (Sankarasubramanian et al., 2001). For example, a streamflow elasticity value of 2 indicates that a $1 \%$ change in mean annual precipitation generates a $2 \%$ change in mean annual flow. Extreme streamflow conditions were analyzed using signatures based on the magnitude, frequency, and duration of high- and low-flow events. High- and low-flow events were defined through long-term thresholds, based on the median and mean flow, respectively (Olden and Poff, 2003). The magnitude of high- and lowflow events was characterized using the 5th and the 95th percentiles. There are two primary limitations to the hydrological signatures used in this study. First, several signatures might scale with catchment area. Since catchment area varies substantially among hydrographic regions, spatial analyses should be carefully conducted. Second, we did not check for temporal dependencies of consecutive high- or low-flow events, for example when two flood peaks occur within a couple of days from each other and both may be related to a single extreme precipitation event. Many criteria exist to identify independent high-flow events (Hall et al., 2014; Archfield et al., 2016) and low-flow events (Fleig et al., 2006; Van Loon, 2015), which might lead to differences in the analyzed signatures.

\subsection{Spatial variability in hydrological signatures}

The spatial distribution of mean daily flows (Fig. 6a) and runoff ratio (Fig. 6b) closely resembles that of mean daily precipitation. These are notably high in southern Brazil and parts of the Amazon and low in northeastern Brazil. The mean half-flow date (i.e., when the cumulative discharge since 1 September reaches half of the annual discharge) follows a gradient ranging from February and March in the eastern Atlantic region to May in the Amazon and on the northern coast (Fig. 6c). Steep slopes of the flow duration curve occur especially in the tributaries of Southern Amazon, the Tocantins-Araguaia basin, the eastern Atlantic hydrographic region and in parts of Southern Brazil (Fig. 6d). Some catchments have undefined values, meaning that they have zero flow for more than $33 \%$ of the time. Since the slopes of the flow duration curve indicate the overall streamflow variability, they are spatially similar to several other hydrological signatures. They are, most noticeably (i) negatively correlated with the baseflow index (Fig. 6e), hence catchments with high baseflow may be highly resilient to dry periods (Fan, 2015); (ii) positively correlated with streamflow precipitation elasticity (Fig. 6f), which indicates variability at the interannual timescale; (iii) negatively correlated with the 5th percentile of streamflow (i.e., low flows; Fig. 61); and (iv) positively correlated with the frequency and duration of low-flow events (Fig. 6j and k). However, note that some regions do not follow those patterns. In particular, catchments in the southern Amazon and in the Tocantins-Araguaia basin have high baseflow indices despite steep slopes of the flow 

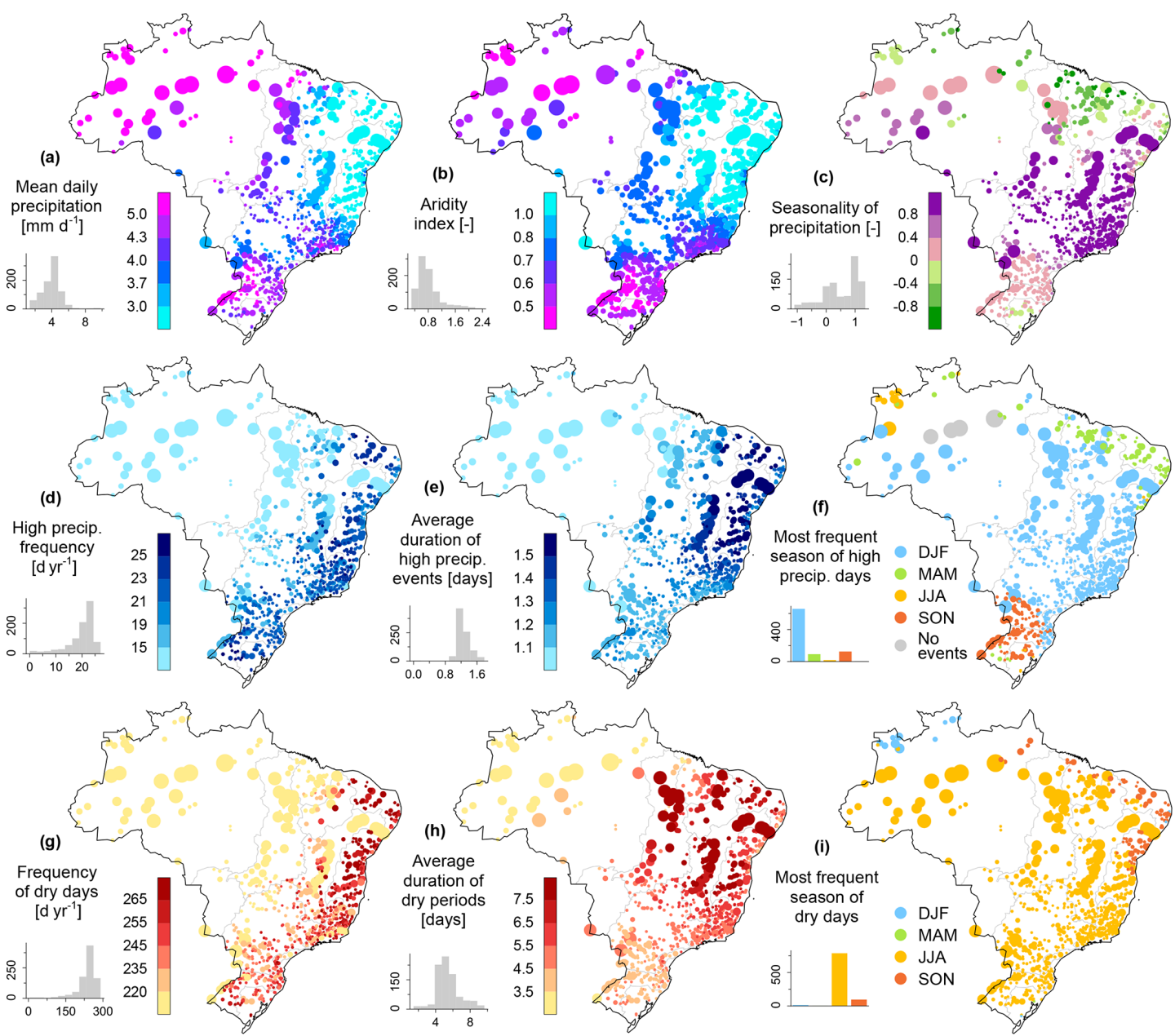

Figure 5. Climatic indices of the 897 selected catchments. The size of the circles is proportional to the size of the catchment. The grey line indicates the limits of hydrographic regions.

duration curve. It possibly implies that the variability in those catchments is related to a high seasonality, rather than to a flashy response to precipitation events.

High-flow days are more frequent and their events are longer in southern Brazil, in the eastern Atlantic region, and on the coast of northeastern Brazil (Fig. $6 \mathrm{~g}$ and $\mathrm{h}$ ). Those regions also have the most frequent and longest low-flow events. This suggests that, in addition to the catchments in the southwestern Amazon and in the Tocantins-Araguaia basin, the extremes of both high and low flows might be related. Catchments seldom have high values in all three highflow signatures, except for in southern Brazil, revealing that this might be the region with the most problematic flood episodes. On the other hand, long and frequent low flows are found in nearly all hydrographic regions. The majority of catchments in the eastern Atlantic and the northeastern Atlantic regions are characterized by long and frequent low flows, where nearly half of those have at least $100 \mathrm{~d}$ of low flows in the year.

\section{Land cover characteristics}

\subsection{Data and methods}

Each catchment was described using 10 land cover classes (Table 5) based on GlobCover2009 (Arino et al., 2012). GlobCover2009 uses imagery from Envisat's Medium Resolution Imaging Spectrometer Instrument Fine Resolution (MERIS FR). The classification has a spatial resolution of $300 \mathrm{~m}$, a global coverage every $3 \mathrm{~d}$ and is based on images from January to December 2009. GlobCover2009 classification includes 22 land cover classes but, to simplify the dataset, we combined these into similar classes. In particular, the class "forests" is a combination of broadleaved and needle-leaved forests, either evergreen or deciduous. Note that GlobCover 2009 does not differentiate between natural or planted forests.

There are three main limitations of the GlobCover2009 dataset. High confusion rates between croplands and grasslands show that the separation of crops, pastures, and mead- 
Table 4. Hydrological signatures. Thresholds for high- and low-flow frequency and duration were obtained from Clausen and Biggs (2000) and Westerberg and McMillan (2015).

\begin{tabular}{|c|c|c|c|}
\hline Attribute & Description & Units & Data source \\
\hline q_mean & Mean daily discharge & $\mathrm{mm} \mathrm{d}^{-1}$ & ANA (2019a) \\
\hline runoff_ratio & $\begin{array}{l}\text { Runoff ratio, computed as the ratio of mean daily discharge to mean daily pre- } \\
\text { cipitation }\end{array}$ & - & ANA (2019a) \\
\hline stream_elas & $\begin{array}{l}\text { Streamflow precipitation elasticity (i.e., the sensitivity of streamflow to changes } \\
\text { in precipitation at the annual timescale, using the mean daily discharge as ref- } \\
\text { erence). See Eq. (7) in Sankarasubramanian et al. (2001), with the last element } \\
\text { being } \bar{P} / \bar{Q} \text { not } \bar{Q} / \bar{P} \text {. }\end{array}$ & - & ANA (2019a) \\
\hline slope_fdc & $\begin{array}{l}\text { Slope of the flow duration curve between the log-transformed 33rd and 66th } \\
\text { streamflow percentiles }\end{array}$ & - & ANA (2019a) \\
\hline baseflow_index & $\begin{array}{l}\text { Baseflow index, computed as the ratio of mean daily baseflow to mean daily dis- } \\
\text { charge, with the hydrograph separation performed using the Ladson et al. (2013) } \\
\text { digital filter }\end{array}$ & - & ANA (2019a) \\
\hline hfd_mean & $\begin{array}{l}\text { Mean half-flow date (i.e., the date on which the cumulative discharge since } \\
1 \text { September reaches half of the annual discharge) }\end{array}$ & day of the year & ANA (2019a) \\
\hline Q5 & $5 \%$ flow quantile (low flow) & $\mathrm{mm} \mathrm{d}^{-1}$ & ANA (2019a) \\
\hline Q95 & $95 \%$ flow quantile (high flow) & $\mathrm{mm} \mathrm{d}^{-1}$ & ANA (2019a) \\
\hline high_q_freq & Frequency of high-flow days ( $>9$ times the median daily flow) & days $\mathrm{yr}^{-1}$ & ANA (2019a) \\
\hline high_q_dur & $\begin{array}{l}\text { Average duration of high-flow events (number of consecutive days }>9 \text { times } \\
\text { the median daily flow) }\end{array}$ & days & ANA (2019a) \\
\hline low_q_freq & Frequency of low-flow days ( $<0.2$ times the mean daily flow) & days $\mathrm{yr}^{-1}$ & ANA (2019a) \\
\hline low_q_dur & $\begin{array}{l}\text { Average duration of low-flow events (number of consecutive days }<0.2 \text { times } \\
\text { the mean daily flow) }\end{array}$ & days & ANA (2019a) \\
\hline zero_q_freq & Percentage of days with zero discharge & $\%$ & ANA (2019a) \\
\hline
\end{tabular}

ows can be problematic, especially in Brazil where those land covers occur extensively. Identification of wetlands is also an issue (Arino et al., 2012) and flooded forests might be underrepresented in the classification. Lastly, GlobCover2009 used the Shuttle Radar Topography Mission (SRTM) Water Body Data, which are based on data from 2000 and do not coincide with the 2009 MERIS data.

\subsection{Spatial variability in land cover characteristics}

Croplands are widespread in Brazil, especially in the highlands, in southern Brazil, and on the eastern coast of northeastern Brazil (Fig. 7a and d). Out of the 897 CAMELSBR catchments, $52.4 \%$ have croplands or mosaics of croplands and natural vegetation as the dominating land cover (Fig. 7c). Croplands are most noticeable particularly in the Uruguay and Paraná hydrographic regions. Even though GlobCover2009 does not cover the same period as the hydrological signatures (i.e., 1990-2009), croplands were already extensive in almost all states in Brazil in the 1980s and pastures in the 1960s (Leite et al., 2012; Dias et al., 2016). This is true except for the southern Amazon, where agricultural expansion has led to one of the highest deforestation rates in the world since the 1980s (Song et al., 2018).

Aside from the Amazon, catchments dominated by forests are located in mountain belts, i.e., in steep slope regions in southern and southeastern Brazil (Fig. 7b). Shrublands occur mainly in the driest regions of the country (Fig. 7e), but they are not the predominant land cover in these regions. Natural wetlands or water bodies are largely present in the Amazon, Tocantins-Araguaia, and Paraguay hydrographic regions (not shown). Some catchments in the Paraná, Uruguay, and São Francisco basins are also substantially covered by water bodies. However, those are mainly artificial reservoirs (see Sect. 9.3). The CAMELS-BR catchments typically have a low fraction of their area considered to be "impervious areas", such as urban land cover; only $0.2 \%$ of the catchments have more than $5 \%$ registered as impervious area (not shown). Besides, grasslands, bare soil areas, and permanent snow are rare in the CAMELS-BR catchments (not shown).

\section{Geologic characteristics}

\subsection{Data and methods}

The geology of the catchments was described using seven geologic attributes (Table 6). The first and second most common geologic class, their fractions, and the percentage of the catchment covered by carbonate rocks were extracted from the Global Lithological Map (GLiM; Hartmann and Moosdorf, 2012). GLiM was created by assembling information from 92 regional lithological maps. In the Brazilian territory, it relies on data from the Brazilian Geological Survey at the $1: 1$ million scale (Schobbenhaus et al., 2004). We consid- 

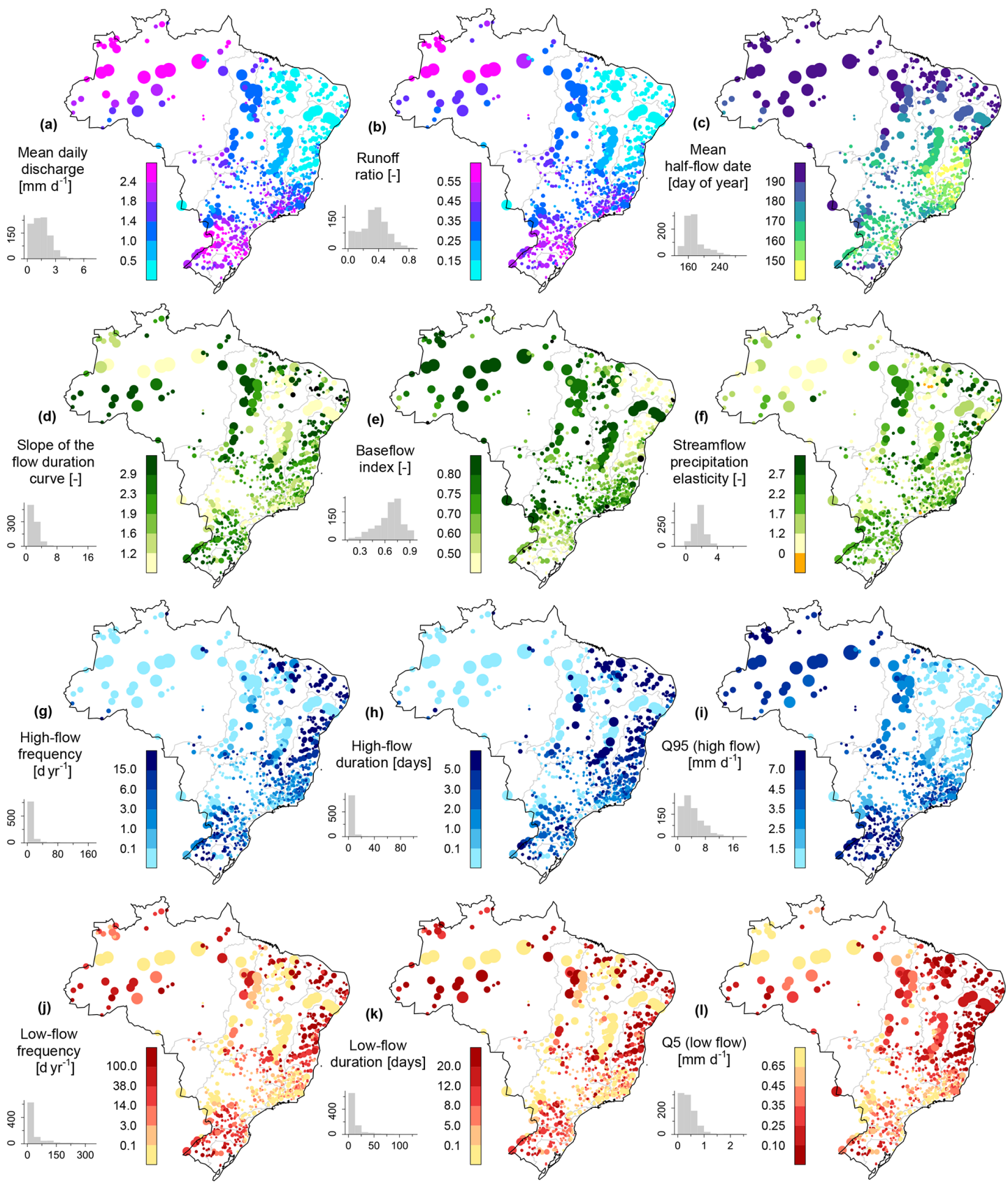

Figure 6. Hydrological signatures of the 897 selected catchments. The black circles are catchments with undefined values. The size of the circles is proportional to the size of the catchment. The grey line indicates the limits of hydrographic regions.

ered only the first level of the GLiM geologic classes, which classifies lithology into 16 groups. The additional second and third levels provide more specific geologic information but were not included in this study. We note that two geologic classes cover a particularly broad variety of rocks. First, the "unconsolidated sediments" class is quite unspecific with regards to the sediment types and grain sizes (it includes sediments originating from areas as alluvial, swamp, and dune deposits). Second, catchments dominated by the "metamor- phic rocks" class can have a wide range of lithologies, from shales to gneiss and quartzite.

We extracted the subsurface permeability and porosity indices from the GLobal HYdrogeology MaPS 2.0 (GLHYMPS; Gleeson et al., 2014; Huscroft et al., 2018), which is modeled based on information from the GLiM and the Global Unconsolidated Sediments Map (GUM; Börker et al., 2018). Subsurface permeability indicates how easily water can flow through the subsurface. GLHYMPS modeled it only 


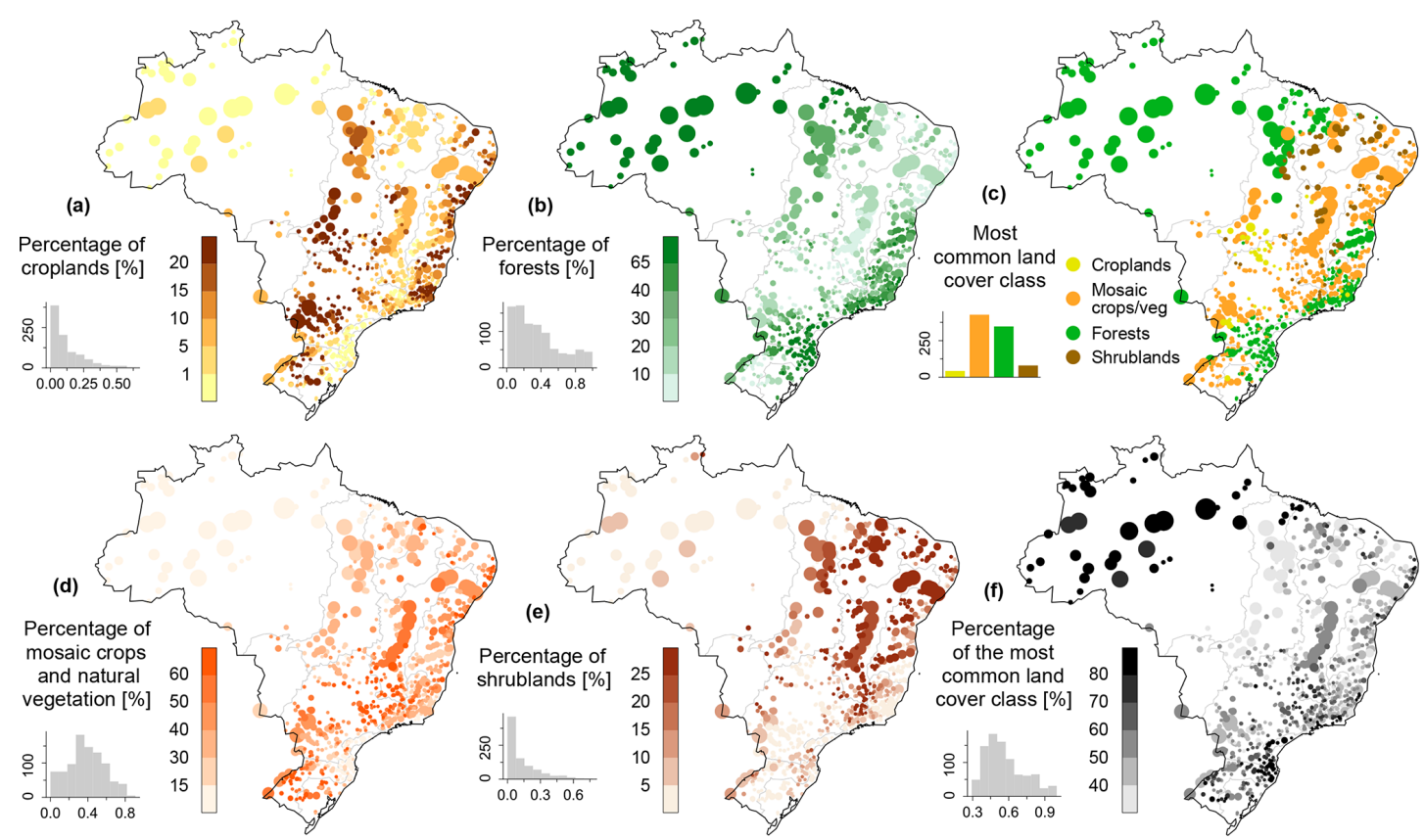

Figure 7. Land cover characteristics of the 897 selected catchments. The size of the circles is proportional to the size of the catchment. The grey line indicates the limits of hydrographic regions.

Table 5. Land cover characteristics.

\begin{tabular}{|c|c|c|c|}
\hline Attribute & Description & Units & Data source \\
\hline crop_perc & Percentage covered by croplands & $\%$ & ESA GlobCover2009 \\
\hline crop_mosaic_perc & Percentage covered by a mosaic of croplands and natural vegetation & $\%$ & ESA GlobCover2009 \\
\hline forest_perc & $\begin{array}{l}\text { Percentage covered by broadleaved or needle-leaved forests, either ev- } \\
\text { ergreen or deciduous }\end{array}$ & $\%$ & ESA GlobCover2009 \\
\hline shrub_perc & Percentage covered by shrublands & $\%$ & ESA GlobCover2009 \\
\hline grass_perc & $\begin{array}{l}\text { Percentage covered by grasslands or areas with sparse }(<15 \%) \text { vege- } \\
\text { tation }\end{array}$ & $\%$ & ESA GlobCover2009 \\
\hline barren_perc & Percentage covered by barren areas & $\%$ & ESA GlobCover2009 \\
\hline imperv_perc & Percentage covered by artificial surfaces or urban areas & $\%$ & ESA GlobCover2009 \\
\hline wet_perc & Percentage covered by water bodies or wetlands & $\%$ & ESA GlobCover2009 \\
\hline snow_perc & Percentage covered by permanent snow or ice & $\%$ & ESA GlobCover2009 \\
\hline dom_land_cover & Dominant land cover & - & ESA GlobCover2009 \\
\hline dom_land_cover_perc & Percentage covered by the dominant land cover & $\%$ & ESA GlobCover2009 \\
\hline
\end{tabular}

for saturated conditions (Huscroft et al., 2018), so it is not adequate to characterize regions dominated by unsaturated processes, e.g., deeply weathered soils. The subsurface porosity indicates the fraction of void spaces in a material and controls the water storage capacity in the subsurface. A major caveat of GLHYMPS data is that it is only adequate for analyses at the regional scale, i.e., over spatial units greater than $5 \mathrm{~km}$ (Gleeson et al., 2014).

\subsection{Spatial variability in geological characteristics}

The catchments on the eastern coast have lithologies dominated by either metamorphic or acid plutonic rocks (Fig. 8a and $b$ ), related to high elevation and steep slopes in this region. These catchments also have low subsurface permeability (Fig. 8g) and the lowest subsurface porosity rates in the country (Fig. 8f). In southern Brazil, basic volcanic lithology is widespread, which encompasses basaltic rocks. Southern Brazil has the most homogeneous lithological types of the country (Fig. 8c and d), where more than $80 \%$ of the catchment areas are usually characterized by a single lithological type. However, subsuperficial porosity and permeability are highly heterogeneous, extending from middle-range to high porosity values and from middle-range to low permeability values. 
Table 6. Geologic characteristics.

\begin{tabular}{llcc}
\hline Attribute & Description & Units & Data source \\
\hline geol_class_1st & Most common geologic class in the catchment & - & GLiM \\
geol_class_1st_perc & Percentage of the catchment covered by the most common geologic class & $\%$ & GLiM \\
geol_class_2nd & Second most common geologic class in the catchment & - & GLiM \\
geol_class_2nd_perc & Percentage of the catchment covered by the second most common geologic class & $\%$ & GLiM \\
carb_rocks_perc & Percentage of the catchment covered by carbonate sedimentary rocks & $\%$ & GLiM \\
geol_porosity & Subsurface porosity of the catchment & - & GLHYMPS v2.0 \\
geol_permeability & Subsurface permeability (log10 scale) of the catchment, extract for each catch- & m $^{2}$ & GLHYMPS v2.0 \\
& ment using the geometric mean & \\
\hline
\end{tabular}
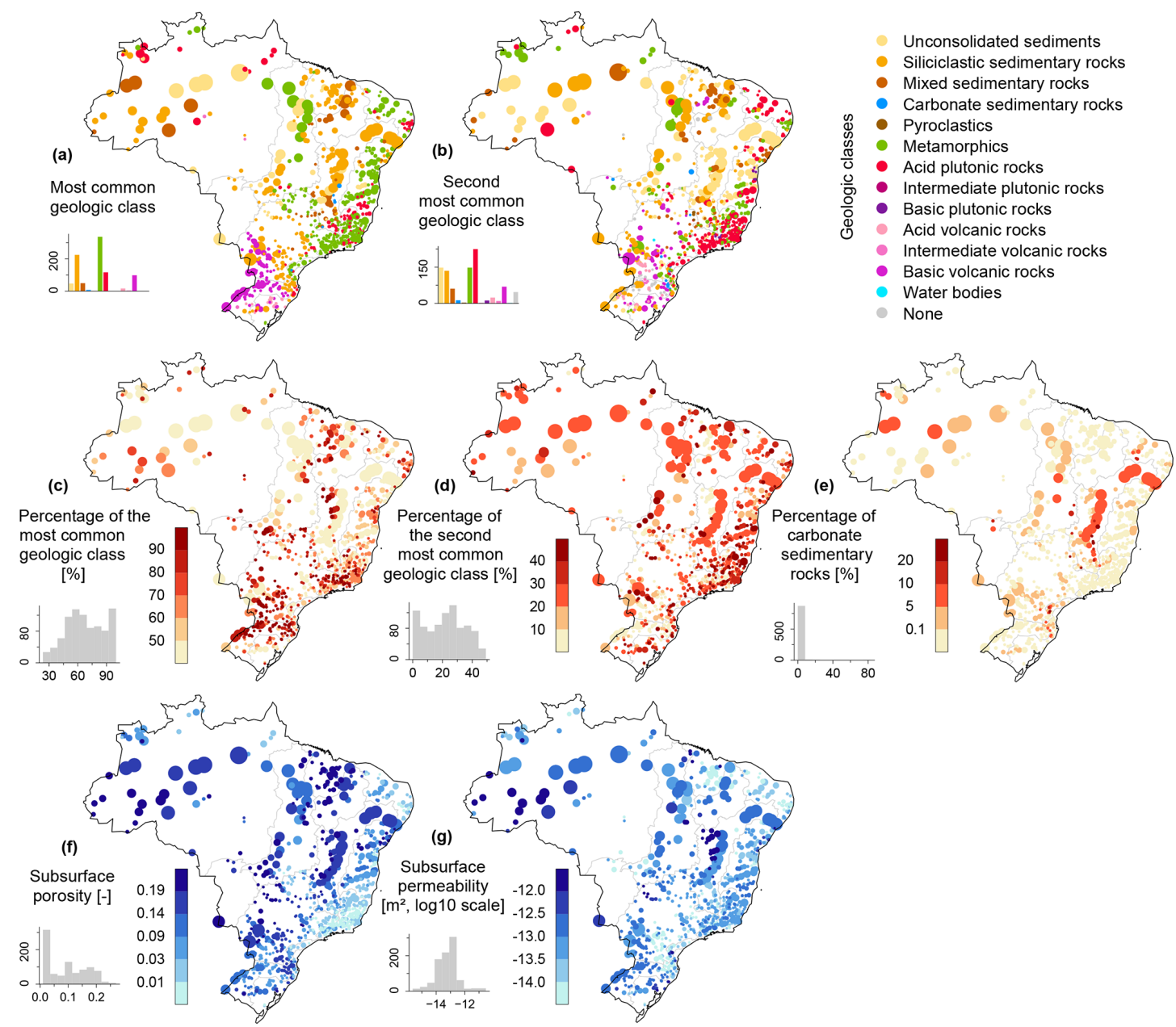

Figure 8. Geologic characteristics of the 897 selected catchments. The size of the circles is proportional to the size of the catchment. The grey line indicates the limits of hydrographic regions.

Sedimentary rocks occur on a large scale at São Francisco, Parnaíba, the western Northeast Atlantic, and part of the Amazon hydrographic region. The northern Amazon is characterized mostly by metamorphic or plutonic rocks, while the western Amazon has either siliciclastic or mixed sedimentary lithologies. On the other hand, unconsolidated sedimentary lithologies particularly occur downstream in the Amazon, the
Tocantins, and the Paraguay basins. These basins also have flat slopes and large proportions of wetlands, which allows for alluvial particles to settle down. Most of the catchments with a high proportion of sedimentary rocks have high subsurface porosity, although their permeability varies according to the grain sizes of these rocks. Carbonate sedimentary rocks, such as karst or limestone, are more common in the 
São Francisco basin and in western Amazon (Fig. 8e). Those rocks are also present in some isolated and smaller catchments in southern Brazil and in the Paraguay and TocantinsAraguaia basins.

\section{Soil characteristics}

\subsection{Data and methods}

We provide six soil characteristics (Table 7). Five of those were extracted from SoilGrids250m (Hengl et al., 2017; Shangguan et al., 2017), a collection of soil maps for the world at the $250 \mathrm{~m}$ resolution. SoilGrids $250 \mathrm{~m}$ maps are the result of a model using approximately 150000 soil profiles, with predictions based on machine learning methods and 158 remote sensing covariates including climate, vegetation, geomorphology, and lithology (Hengl et al., 2017). Although SoilGrids $250 \mathrm{~m}$ generated predictions for several soil depths, in this work we only computed soil characteristics over a depth of $30 \mathrm{~cm}$. SoilGrids $250 \mathrm{~m}$ is based on a machine learning model that explains large proportions of the variance of most observed variables, including $69 \%$ of the variance of organic carbon content and more than $70 \%$ of the soil textures (i.e., clay, silt, and sand content).

The soil characteristics might be highly correlated with other attributes from CAMELS-BR since they are modeled based on climatic and landscape covariates. Organic carbon content and clay content have modeled depth to bedrock as a predominant variable (Hengl et al., 2017). Other variables are also important, such as temperature and geomorphological characteristics (e.g., surface slope). The predictions of sand content are based primarily on depth to bedrock and precipitation, both at similar weights. Out of the five variables considered from the SoilGrids $250 \mathrm{~m}$, predictions of depth to bedrock is the most problematic, with $59 \%$ of its variance explained by the model (Shangguan et al., 2017). It has precipitation as the predominant covariate, which accounts for the control of weathering rates and soil production. Other decisive covariates are vegetation dynamics and geomorphological characteristics, which account for factors such as soil erosion (Shangguan et al., 2017).

The sixth soil characteristic is the water table depth, based on a $1 \mathrm{~km}$ resolution global model by Fan et al. (2013). Combined with depth to bedrock, water table depth can be an indicator of water storage potential in the catchment, which is related to baseflow and the supply of water for the vegetation during dry periods (Fan et al., 2013, 2019). The most important variables in the predictions of the water table depth of that model are, in decreasing order of importance, surface slope, elevation, precipitation, and temperature (Fan et al., 2013). Note that groundwater abstractions are not represented in the model, so water table depth data must be used with caution when analyzing catchments with intense anthropogenic intervention.

\subsection{Spatial variability in soil characteristics}

Soil texture in CAMELS-BR is characterized by (i) a predominance of clay content in southern Brazil, in parts of southeastern Brazil (particularly at higher elevations), and in the northeastern Amazon (Fig. 9c); (ii) similar values of clay, sand, and silt content in the southern tributaries of the western Amazon (Figs. 9a to 8c); and (iii) a wide predominance of sand content in the rest of the country (Fig. 9a). As expected, the aridity index is closely related to the spatial distribution of the soil texture, since climatic attributes are important covariates in SoilGrids250m predictions (Hengl et al., 2017). The predominance of clay in southern Brazil and in part of southeastern Brazil might be linked to their lithological classes, i.e., with basic volcanic rocks in the former and acid plutonic rocks in the latter since they have coincidental spatial distributions.

Organic carbon content is most pronounced in parts of the Amazon and in regions with high clay content (Fig. 9d). The depth to bedrock is higher in central and northeastern Brazil, frequently above $30 \mathrm{~m}$ (Fig. 9e). On the other hand, only $14 \%$ of the catchments have depths to bedrock lower than $10 \mathrm{~m}$, all of which are located in southern Brazil. Regarding water table depths, there is a clear gradient with higher depths on the eastern coast of Brazil (i.e., exceeding $30 \mathrm{~m}$ deep) to lower depths towards the Amazon (i.e., less than $10 \mathrm{~m}$ deep). Amongst all six soil characteristics indices, water table depth has the lowest correspondence to climate, i.e., to mean precipitation and aridity index. It is mostly correlated with catchment slopes, as previously indicated by Fan et al. (2013).

\section{Human intervention indices}

\subsection{Data and methods for consumptive water use}

We computed four indices of human intervention in the catchments (Table 8). Two are the total consumptive water use in the catchment in 2017, one normalized by catchment areas and another normalized by mean annual streamflow. Consumptive water use refers to water withdrawals that do not return to the catchment, for example, by evaporating, transpiring, or being incorporated into manufactured products. The water uses are based on the Manual of Consumptive Water Use in Brazil (ANA, 2019c), which estimated the monthly water use of each municipality in Brazil. These estimates are the sum of water demands from six categories.

i. Irrigation. Demand based on water balance models that estimate the quantity of water needed by irrigated crops but not supplied by precipitation or soil moisture (ANA, 2019c). The spatial extent of irrigated croplands was characterized using the national censuses of agriculture (e.g., IBGE, 2007) and remote sensing images from Landsat, Sentinel-2, and Moderate-Resolution Imaging Spectroradiometer (MODIS) (ANA, 2019b). 
Table 7. Soil characteristics.

\begin{tabular}{llll}
\hline Attribute & Description & Units & Data source \\
\hline sand_perc & Percentage of sand content of the soil material smaller than $2 \mathrm{~mm}$ at a depth of & $\%$ & SoilGrids $250 \mathrm{~m}$ \\
& $30 \mathrm{~cm}$ & & \\
silt_perc & Percentage of silt content of the soil material smaller than $2 \mathrm{~mm}$ at a depth of $30 \mathrm{~cm}$ & $\%$ & SoilGrids $250 \mathrm{~m}$ \\
clay_perc & Percentage of clay content of the soil material smaller than $2 \mathrm{~mm}$ at a depth of $30 \mathrm{~cm}$ & $\%$ & SoilGrids $250 \mathrm{~m}$ \\
org_carbon_content & Soil organic carbon content at a soil depth of $30 \mathrm{~cm}$ & $\mathrm{~g} \mathrm{~kg}^{-1}$ & SoilGrids $250 \mathrm{~m}$ \\
bedrock_depth & Depth to bedrock & $\mathrm{cm}$ & SoilGrids $250 \mathrm{~m}$ \\
water_table_depth & Median water table depth & $\mathrm{cm}$ & Fan et al. (2013) \\
\hline
\end{tabular}
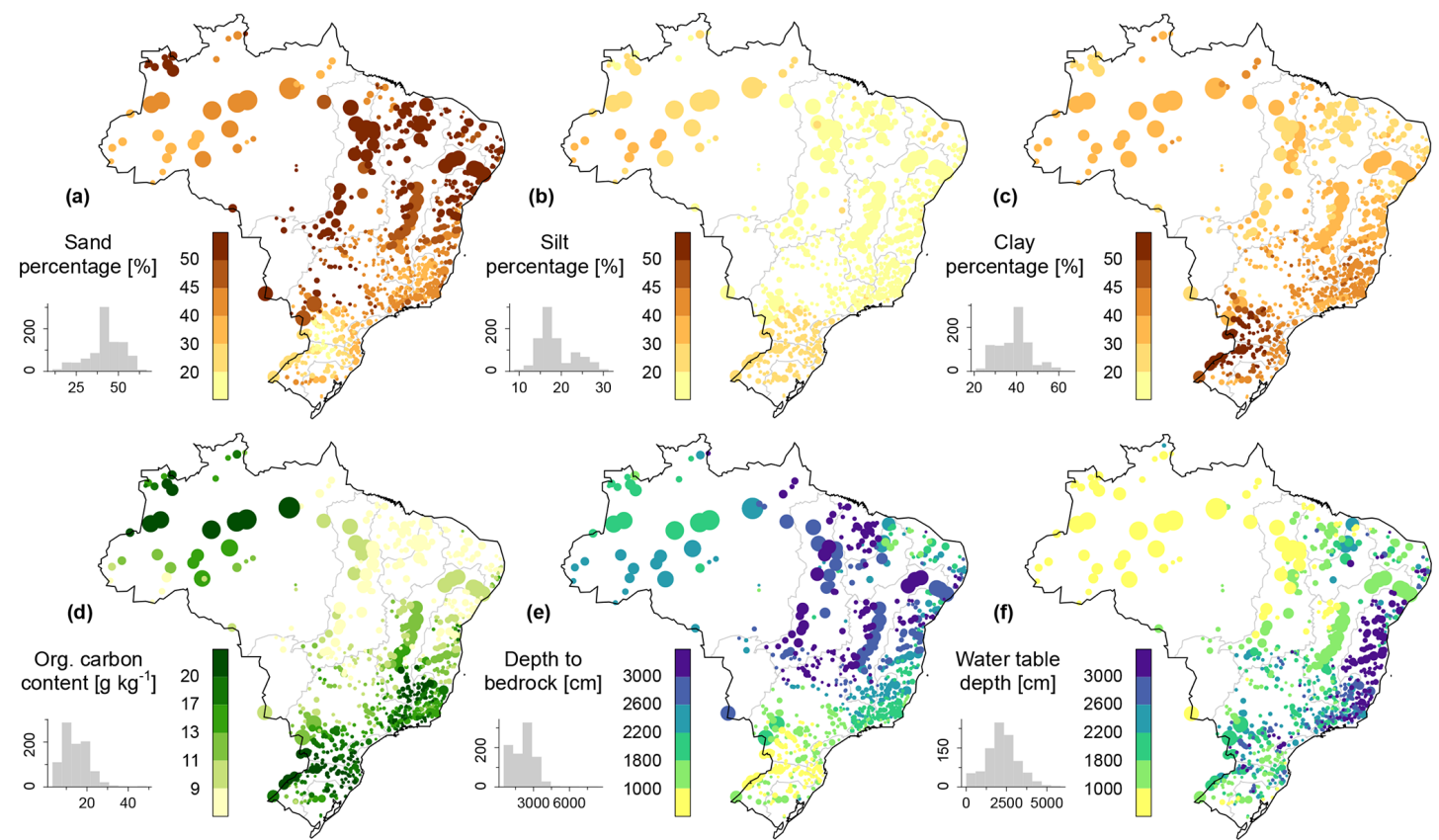

Figure 9. Soil characteristics of the 897 selected catchments. The size of the circles is proportional to the size of the catchment. The grey line indicates the limits of hydrographic regions.

ii. Livestock. Demand estimated by multiplying the number of livestock units with their corresponding daily drinking requirements. The number and type of livestock of each municipality were mapped on the national censuses of agriculture.

iii. Households. Demand estimated by multiplying the number of people in a municipality by their per capita domestic water use.

iv. Industry. Demand estimated by multiplying the number of employees in several industrial categories from each municipality by its per capita water use.

v. Mining. Demand estimated by combining the water use coefficient with the annual production of several types of mineral extraction. vi. Thermoelectricity. Demand estimated by applying a water use coefficient to the annual electricity production of each thermoelectric plant in the country.

These water demand estimates do not differentiate surface water from groundwater. Even though groundwater abstraction is extensive in the eastern part of Brazil (Fan et al., 2013), it is estimated that most of the water use in South America comes from surface water (Wada et al., 2014). To estimate the consumptive water use of each catchment, we divided the values of each municipality by its area. We assumed the water use to be spatially homogeneous throughout the municipality territory and transferred the data for each municipality onto a $500 \mathrm{~m}$ spatial resolution raster.

There are three major limitations of using consumptive water use estimated by ANA (2019c). First, evaporation from artificial reservoirs was not included in the computation. Thus, water use might be underestimated, particularly in the northeastern part of Brazil, i.e., in the driest part of the coun- 
try. Second, the dataset comes on an irregular grid, since municipalities areas vary significantly. The smallest municipalities are usually within $500 \mathrm{~km}$ of the coast, and their areas are mostly a few hundred square kilometers. In contrast, the western part of Brazil and the Amazon usually have municipalities larger than $1000 \mathrm{~km}^{2}$. Hence, consumptive water use of small catchments in the western part of Brazil should be interpreted with caution because they are smaller than the input data. The third limitation is that the consumptive water use of South America outside Brazil was not estimated by ANA (2019c) and was not considered in this study. This particularly affects the basins in the Amazon since they cover large parts out of Brazil. That said, anthropic intervention in these basins is low: only three basins with international borders in the Amazon are more than $10 \%$ covered by croplands or a cropland and natural vegetation mosaic, and none have more than $0.05 \%$ of impervious land cover, such as urban areas.

\subsection{Data and methods for reservoirs}

The other two indices for human intervention are related to flow regulation (Table 8), i.e., the sum of the total storage capacity of all reservoirs in the catchment and its ratio to the total annual flow of the catchment (i.e., the degree of regulation). We worked with estimated storage capacities from 1406 reservoirs in South America. The reservoirs were mapped by combining three data sources: (i) the Global Reservoirs and Dam database v1.3 (GRanD; Lehner et al., 2011); (ii) the hydroelectric power plants database of the National Electrical System Operator (ONS, 2019); and (iii) the 2017 National Dam Safety Report (ANA, 2018) database. The GRanD database includes reservoirs throughout South America, while the other two provided data only for Brazil. The procedure for combining the three databases was as follows.

i. We included all reservoirs from GRanD v1.3 in South America.

ii. For each GRanD reservoir, we visually compared the inundated area with the one indicated by the polygons from the water bodies maps from Pekel et al. (2016). When the inundated areas differed substantially, we substituted the former with the latter and updated the size of the inundated area.

iii. Out of more than 24000 reservoirs from the ONS (2019) and ANA (2018) databases, we included only those that have their inundated areas (Pekel et al., 2016) visible at the $1: 500000$ scale. Although our goal was to only include reservoirs larger than approximately $0.5 \mathrm{~km}^{2}$, some smaller reservoirs were also included. We computed the size of the inundated areas of those reservoirs according to the polygons from Pekel et al. (2016). iv. To check for duplicates in the databases, we manually inspected all dam points and their inundated areas.

v. Finally, the storage capacities of reservoirs updated in step (ii) or included in step (iii) were recalculated using their inundated areas and, when available, information on dam height. We applied two equations determined by Lehner et al. (2011, Technical Document) with a statistical regression using data from 5824 reservoirs worldwide. When information on dam height was available, we applied Eq. (1):

$$
V=0.678(A h)^{0.9229} \text {, }
$$

where $V$ is the reservoir storage capacity in $10^{6} \mathrm{~m}^{3}, A$ is the size of the inundated area in square kilometers, and $h$ is dam height in meters. When information on dam height was not available, we used Eq. (2):

$$
V=30.684 A^{0.9578} \text {. }
$$

\subsection{Spatial variability in human intervention indices}

The spatial distribution of human interference indices reveals that, unlike the catchments in the original CAMELS for the United States, catchments in CAMELS-BR can be significantly impacted by human activities. There are $17.8 \%$ of catchments with annual consumptive water uses greater than $5 \%$ of the mean annual flow. Those are principally in the driest parts of the country, i.e., in the São Francisco, eastern Atlantic, eastern Northeast Atlantic, and upper Paraná hydrographic regions (Fig. 10b). Nevertheless, water uses greater than $20 \%$ of the mean annual flow are rare, occurring in only $3.9 \%$ of the catchments. The similarity encountered between arid climates and high consumptive water uses may be attributed to two main causes. First, in the most arid catchments, the mean annual flow is typically a third of that of the rest of the country, which unsurprisingly leads to higher water uses proportional to the annual flow. Second, crops in drier climates require frequent irrigation and considerable rates of water withdrawal. On the other hand, we observe that the central and southeastern regions of Brazil have the greatest values of water uses normalized by catchment area (Fig. 10a). Catchments in those regions are commonly occupied by either irrigated croplands or populous metropolitan areas, which are respectively the first and second categories with the highest water demands in Brazil (ANA, 2019c).

The degree of regulation is related to catchment area (Fig. 10c), meaning that the most regulated basins are downstream in the river basins. The main rivers with high regulations are the Paraná, Uruguay, São Francisco, TocantinsAraguaia, Parnaíba, and Paraíba do Sul rivers. In those regions, $19.2 \%$ and $7.2 \%$ of the catchments have a degree of regulation greater than $10 \%$ and $50 \%$, respectively. These values nearly double in the driest regions of the country (i.e., the eastern Atlantic, São Francisco, eastern Northeast 
Table 8. Human intervention indices.

\begin{tabular}{llll}
\hline Attribute & Description & Units & Data source \\
\hline consumptive_use & $\begin{array}{l}\text { Total consumptive water use in 2017, normalized by catch- } \\
\text { ment area }\end{array}$ & mm yr $^{-1}$ & ANA (2019c) \\
consumptive_use_perc & $\begin{array}{l}\text { Total consumptive water use in 2017, normalized by mean } \\
\text { annual streamflow }\end{array}$ & $\%$ & ANA (2019c) \\
reservoirs_vol & $\begin{array}{l}\text { Total maximum storage capacity of the reservoirs in the } \\
\text { catchment }\end{array}$ & $10^{6} \mathrm{~m}^{3}$ & GRanD v1.3, ONS, and ANA (2018) \\
regulation_degree & $\begin{array}{l}\text { Ratio of total reservoir storage capacity of the catchment to } \\
\text { its total annual flow }\end{array}$ & GRanD v1.3, ONS, and ANA (2018) \\
\hline
\end{tabular}

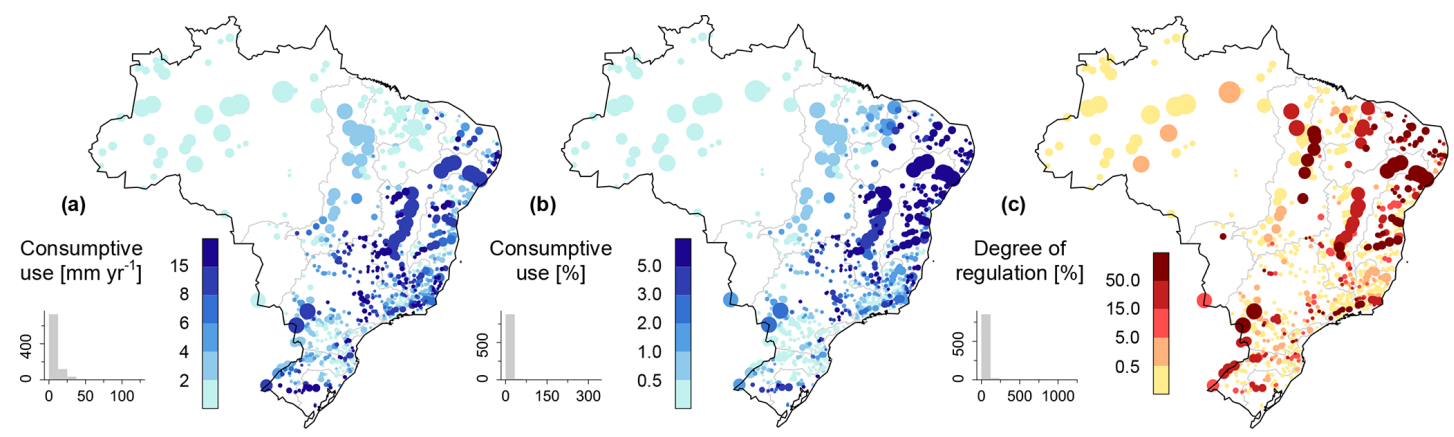

Figure 10. Human intervention indices of the 897 selected catchments. The size of the circles is proportional to the size of the catchment. The grey line indicates the limits of hydrographic regions.

Atlantic, and Parnaíba hydrographic regions): $37.6 \%$ and $22.1 \%$ of the catchments have a degree of regulation greater than $10 \%$ and $50 \%$, respectively. Therefore, the driest catchments of CAMELS-BR dataset have the highest human intervention rates, both in terms of consumptive water use and reservoir regulation.

\section{Data availability}

The CAMELS-BR dataset is freely available at https://doi.org/10.5281/zenodo.3709337 (Chagas et al., 2020). The files provided are (i) the 65 attributes in a zip file, (ii) the daily time series in zip files, (iii) the catchment boundaries used to compute the attributes and extract the time series computed by Do et al. (2018) and Gudmundsson et al. (2018), and (iv) a readme file.

\section{Conclusions}

So far, large-sample hydrological studies in Brazil lacked a comprehensive and easily accessible dataset. Here, we introduced the CAMELS-BR, a new dataset comprising streamflow time series for 3679 catchments in Brazil and, for a selected quality-controlled set of 897 catchments, meteorological time series and 65 catchment attributes. The attributes cover a wide range of fundamental properties for large-sample hydrological research, such as topography, land cover, geology, soil, and human intervention characteristics. We strived to make CAMELS-BR as comparable as possible to the other CAMELS datasets (Addor et al., 2017; AlvarezGarreton et al., 2018) by using common naming conventions, scripts, and datasets. We also discuss the major limitations of the data to limit the risk of misinterpretation and misuse.

Even though CAMELS-BR is a step forward for hydrological research in Brazil, there are several opportunities for expanding the dataset in the future. For example, future versions of CAMELS-BR could include additional catchment attributes critical to understanding hydrological processes, such as drainage density and basin morphometry (Shen et al., 2017). Further, an updated version should better characterize heterogeneities within each catchment, both for the time series and attributes. Additionally, since data uncertainties are omnipresent (Montanari, 2007; Blöschl et al., 2019b; Addor et al., 2019), they should be further explored by including additional data sources.

By simplifying the access to hydrological data, we aim to encourage further large-sample hydrological studies in Brazil, facilitate the inclusion of Brazilian catchments in global large-sample studies, increase the transparency and reproducibility of these studies. We believe the data introduced here will, in particular, prove useful to explore the drivers of catchment behavior, anticipate hydrological changes, and study the impacts of human activities on the water cycle. We see CAMELS-BR as a resource designed to serve the broad 
water science community and to help with water resources management at regional, national, and continental scales.

Author contributions. PLBC and VBPC initiated the investigation. VBPC, PLBC, NA, FMF, ASF, RCDP, and VAS designed the study. VBPC processed the data and created the figures. VBPC and NA computed the catchment attributes. VBPC prepared the manuscript with contributions from all co-authors.

Competing interests. The authors declare that they have no conflict of interest.

Acknowledgements. Vinícius B. P. Chagas would like to thank CNPq (Brazilian National Council for Scientific and Technological Development) for the scholarship. Nans Addor acknowledges support from the Swiss National Sciences Foundation (P400P2_180791).

Review statement. This paper was edited by Ge Peng and reviewed by Thibault Mathevet, Wouter Knoben, and one anonymous referee.

\section{References}

Addor, N., Newman, A. J., Mizukami, N., and Clark, M. P.: The CAMELS data set: catchment attributes and meteorology for large-sample studies, Hydrol. Earth Syst. Sci., 21, 5293-5313, https://doi.org/10.5194/hess-21-5293-2017, 2017.

Addor, N., Do, H. X., Alvarez-Garreton, C., Coxon, G., Fowler, K., and Mendoza, P. A.: Large-sample hydrology: recent progress, guidelines for new datasets and grand challenges, Hydrolog. Sci. J., 1-14, https://doi.org/10.1080/02626667.2019.1683182, 2019.

Alfieri, L., Lorini, V., Hirpa, F. A., Harrigan, S., Zsoter, E., Prudhomme, C., and Salamon, P.: A global streamflow reanalysis for 1980-2018, J. Hydrol., 6, 100049, https://doi.org/10.1016/j.hydroa.2019.100049, 2020.

Alvarez-Garreton, C., Mendoza, P. A., Boisier, J. P., Addor, N., Galleguillos, M., Zambrano-Bigiarini, M., Lara, A., Puelma, C., Cortes, G., Garreaud, R., McPhee, J., and Ayala, A.: The CAMELS-CL dataset: catchment attributes and meteorology for large sample studies - Chile dataset, Hydrol. Earth Syst. Sci., 22, 5817-5846, https://doi.org/10.5194/hess-22-5817-2018, 2018.

ANA - Brazilian National Water Agency: Relatorio de Seguranca de Barragens 2017, 2018.

ANA - Brazilian National Water Agency, HIDROWEB: available at: http://www.snirh.gov.br/hidroweb (last access: 15 June 2019), 2019a.

ANA - Brazilian National Water Agency: Levantamento Da Agricultura Irrigada Por Pivôs Centrais No Brasil (1985-2017), 2a edição, 2019b.

ANA - Brazilian National Water Agency: Manual De Usos Consuntivos Da Água No Brasil, 2019c.

Archfield, S. A., Hirsch, R. M., Viglione, A. and Blöschl, G.: Fragmented patterns of flood change across the
United States, Geophys. Res. Lett., 43, 10232-10239, https://doi.org/10.1002/2016GL070590, 2016.

Arino, O., Perez, J. J. R., Kalogirou, V., Bontemps, S., Defourny, P., and Bogaert, E. V.: Global Land Cover Map for 2009 (GlobCover 2009), PANGAEA, https://doi.org/10.1594/PANGAEA.787668, 2012.

Bartiko, D., Oliveira, D. Y., Bonumá, N. B., and Chaffe, P. L. B.: Spatial and seasonal patterns of flood change across Brazil, Hydrolog. Sci. J., 64, 1071-1079, https://doi.org/10.1080/02626667.2019.1619081, 2019.

Beck, H. E., van Dijk, A. I., De Roo, A., Miralles, D. G., McVicar, T. R., Schellekens, J., and Bruijnzeel, L. A.: Global-scale regionalization of hydrologic model parameters, Water Resour. Res., 52, 3599-3622, 2016.

Beck, H. E., van Dijk, A. I. J. M., de Roo, A., Dutra, E., Fink, G., Orth, R., and Schellekens, J.: Global evaluation of runoff from 10 state-of-the-art hydrological models, Hydrol. Earth Syst. Sci., 21, 2881-2903, https://doi.org/10.5194/hess-21-2881-2017, 2017a.

Beck, H. E., van Dijk, A. I. J. M., Levizzani, V., Schellekens, J., Miralles, D. G., Martens, B., and de Roo, A.: MSWEP: 3hourly $0.25^{\circ}$ global gridded precipitation (1979-2015) by merging gauge, satellite, and reanalysis data, Hydrol. Earth Syst. Sci., 21, 589-615, https://doi.org/10.5194/hess-21-589-2017, $2017 \mathrm{~b}$.

Beck, H. E., Vergopolan, N., Pan, M., Levizzani, V., van Dijk, A. I. J. M., Weedon, G. P., Brocca, L., Pappenberger, F., Huffman, G. J., and Wood, E. F.: Global-scale evaluation of 22 precipitation datasets using gauge observations and hydrological modeling, Hydrol. Earth Syst. Sci., 21, 6201-6217, https://doi.org/10.5194/hess-21-6201-2017, 2017c.

Beck, H. E., Wood, E. F., Pan, M., Fisher, C. K., Miralles, D. G., van Dijk, A. I. J. M., McVicar, T. R., and Adler, R. F.: MSWEP V2 Global 3-Hourly $0.1^{\circ}$ Precipitation: Methodology and Quantitative Assessment, B. Am. Meteorol. Soc., 100, 473500, https://doi.org/10.1175/BAMS-D-17-0138.1, 2019.

Bierkens, M. F.: Global hydrology 2015: State, trends, and directions, Water Resour. Res., 51, 4923-4947, 2015.

Berghuijs, W. R. and Woods, R. A.: A simple framework to quantitatively describe monthly precipitation and temperature climatology, Int. J. Climatol., 36, 3161-3174, https://doi.org/10.1002/joc.4544, 2016.

Berghuijs, W. R., Sivapalan, M., Woods, R. A., and Savenije, H. H. G.: Patterns of similarity of seasonal water balances: A window into streamflow variability over a range of time scales, Water Resour. Res., 50, 5638-5661, https://doi.org/10.1002/2014WR015692, 2014.

Blöschl, G., Sivapalan, M., Savenije, H., Wagener, T., and Viglione, A. (Eds.): Runoff prediction in ungauged basins: synthesis across processes, places and scales, Cambridge University Press, Cambridge, UK, 465 pp., 2013.

Blöschl, G., Hall, J., Viglione, A., Perdigão, R. A. P., Parajka, J., Merz, B., Lun, D., Arheimer, B., Aronica, G. T., Bilibashi, A., Boháč, M., Bonacci, O., Borga, M., Čanjevac, I., Castellarin, A., Chirico, G. B., Claps, P., Frolova, N., Ganora, D., Gorbachova, L., Gül, A., Hannaford, J., Harrigan, S., Kireeva, M., Kiss, A., Kjeldsen, T. R., Kohnová, S., Koskela, J. J., Ledvinka, O., Macdonald, N., Mavrova-Guirguinova, M., Mediero, L., Merz, R., Molnar, P., Montanari, A., Murphy, C., Osuch, M., Ovcharuk, V., Radevski, I., Salinas, J. L., Sauquet, E., Šraj, M., Szolgay, J., Volpi, E., Wilson, D., Zaimi, K., and Živković, N.: Changing 
climate both increases and decreases European river floods, Nature, 573, 108-111, https://doi.org/10.1038/s41586-019-1495-6, 2019a.

Blöschl, G., Bierkens, M. F. P., Chambel, A., Cudennec, C., Destouni, G., Fiori, A., Kirchner, J. W., McDonnell, J. J., Savenije, H. H. G., Sivapalan, M., Stumpp, C., Toth, E., Volpi, E., Carr, G., Lupton, C., Salinas, J., Széles, B., Viglione, A., Aksoy, H., Allen, S. T., Amin, A., Andréassian, V., Arheimer, B., Aryal, S. K., Baker, V., Bardsley, E., Barendrecht, M. H., Bartosova, A., Batelaan, O., Berghuijs, W. R., Beven, K., Blume, T., Bogaard, T., Borges de Amorim, P., Böttcher, M. E., Boulet, G., Breinl, K., Brilly, M., Brocca, L., Buytaert, W., Castellarin, A., Castelletti, A., Chen, X., Chen, Y., Chen, Y., Chifflard, P., Claps, P., Clark, M. P., Collins, A. L., Croke, B., Dathe, A., David, P. C., de Barros, F. P. J., de Rooij, G., Di Baldassarre, G., Driscoll, J. M., Duethmann, D., Dwivedi, R., Eris, E., Farmer, W. H., Feiccabrino, J., Ferguson, G., Ferrari, E., Ferraris, S., Fersch, B., Finger, D., Foglia, L., Fowler, K., Gartsman, B., Gascoin, S., Gaume, E., Gelfan, A., Geris, J., Gharari, S., Gleeson, T., Glendell, M., Gonzalez Bevacqua, A., González-Dugo, M. P., Grimaldi, S., Gupta, A. B., Guse, B., Han, D., Hannah, D., Harpold, A., Haun, S., Heal, K., Helfricht, K., Herrnegger, M., Hipsey, M., Hlaváčiková, H., Hohmann, C., Holko, L., Hopkinson, C., Hrachowitz, M., Illangasekare, T. H., Inam, A., Innocente, C., Istanbulluoglu, E., Jarihani, B., et al.: Twenty-three unsolved problems in hydrology (UPH) a community perspective, Hydrolog. Sci. J., 64, 1141-1158, https://doi.org/10.1080/02626667.2019.1620507, 2019b.

Börker, J., Hartmann, J., Amann, T., and Romero-Mujalli, G.: Terrestrial Sediments of the Earth: Development of a Global Unconsolidated Sediments Map Database (GUM), Geochem. Geophy. Geosy., 19, 997-1024, https://doi.org/10.1002/2017GC007273, 2018

Budyko, M. I.: Climate and life, Academic press New York, 1974.

Carvalho, L. M. V., Jones, C., Silva, A. E., Liebmann, B., and Silva Dias, P. L.: The South American Monsoon System and the 1970s climate transition, Int. J. Climatol., 31, 1248-1256, https://doi.org/10.1002/joc.2147, 2011.

Chagas, V. B. P. and Chaffe, P. L. B.: The Role of Land Cover in the Propagation of Rainfall Into Streamflow Trends, Water Resour. Res., 54, 5986-6004, https://doi.org/10.1029/2018WR022947, 2018

Chagas, V. B. P., Chaffe, P. L. B., Addor, N., Fan, F. M., Fleischmann, A. S., Paiva, R. C. D., and Siqueira, V. A.: CAMELS-BR: Hydrometeorological time series and landscape attributes for 897 catchments in Brazil - link to files, Zenodo, https://doi.org/10.5281/zenodo.3709337, 2020.

Clausen, B. and Biggs, B. J. F.: Flow variables for ecological studies in temperate streams: groupings based on covariance, J. Hydrol., 237, 184-197, https://doi.org/10.1016/S0022-1694(00)00306-1, 2000.

Collischonn, W., Tucci, C. E. M., and Clarke, R. T.: Further evidence of changes in the hydrological regime of the River Paraguay: part of a wider phenomenon of climate change?, J. Hydrol., 245, 218-238, https://doi.org/10.1016/S00221694(01)00348-1, 2001

Coxon, G., Addor, N., Bloomfield, J. P., Freer, J., Fry, M., Hannaford, J., Howden, N. J. K., Lane, R., Lewis, M., Robinson, E. L., Wagener, T., and Woods, R.: CAMELS-GB: Hy- drometeorological time series and landscape attributes for 671 catchments in Great Britain, Earth Syst. Sci. Data Discuss., https://doi.org/10.5194/essd-2020-49, in review, 2020.

Crochemore, L., Isberg, K., Pimentel, R., Pineda, L., Hasan, A., and Arheimer, B.: Lessons learnt from checking the quality of openly accessible river flow data worldwide, Hydrolog. Sci. J., 65, 699711, https://doi.org/10.1080/02626667.2019.1659509, 2019.

Dias, L. C. P., Pimenta, F. M., Santos, A. B., Costa, M. H., and Ladle, R. J.: Patterns of land use, extensification, and intensification of Brazilian agriculture, Glob. Change Biol., 22, 2887-2903, https://doi.org/10.1111/gcb.13314, 2016.

Di Baldassarre, G., Wanders, N., AghaKouchak, A., Kuil, L., Rangecroft, S., Veldkamp, T. I. E., Garcia, M., van Oel, P. R., Breinl, K., and Van Loon, A. F.: Water shortages worsened by reservoir effects, Nat. Sustain., 1, 617-622, https://doi.org/10.1038/s41893-018-0159-0, 2018.

Do, H. X., Gudmundsson, L., Leonard, M., and Westra, S.: The Global Streamflow Indices and Metadata Archive (GSIM) - Part 1: The production of a daily streamflow archive and metadata, Earth Syst. Sci. Data, 10, 765-785, https://doi.org/10.5194/essd10-765-2018, 2018.

Döll, P., Douville, H., Güntner, A., Schmied, H. M., and Wada, Y.: Modelling freshwater resources at the global scale: challenges and prospects, Surv. Geophys., 37, 195-221, 2016.

Ehret, U., Gupta, H. V., Sivapalan, M., Weijs, S. V., Schymanski, S. J., Blöschl, G., Gelfan, A. N., Harman, C., Kleidon, A., Bogaard, T. A., Wang, D., Wagener, T., Scherer, U., Zehe, E., Bierkens, M. F. P., Di Baldassarre, G., Parajka, J., van Beek, L. P. H., van Griensven, A., Westhoff, M. C., and Winsemius, H. C.: Advancing catchment hydrology to deal with predictions under change, Hydrol. Earth Syst. Sci., 18, 649-671, https://doi.org/10.5194/hess-18-649-2014, 2014.

Fan, Y.: Groundwater in the Earth's critical zone: Relevance to large-scale patterns and processes: Groundwater at large scales, Water Resour. Res., 51, 3052-3069, https://doi.org/10.1002/2015WR017037, 2015.

Fan, Y., Li, H., and Miguez-Macho, G.: Global Patterns of Groundwater Table Depth, Science, 339, 1-5, https://doi.org/10.1126/science.1229881, 2013.

Fan, Y., Clark, M., Lawrence, D. M., Swenson, S., Band, L. E., Brantley, S. L., Brooks, P. D., Dietrich, W. E., Flores, A., Grant, G., Kirchner, J. W., Mackay, D. S., McDonnell, J. J., Milly, P. C. D., Sullivan, P. L., Tague, C., Ajami, H., Chaney, N., Hartmann, A., Hazenberg, P., McNamara, J., Pelletier, J., Perket, J., Rouholahnejad-Freund, E., Wagener, T., Zeng, X., Beighley, E., Buzan, J., Huang, M., Livneh, B., Mohanty, B. P., Nijssen, B., Safeeq, M., Shen, C., Verseveld, W., Volk, J., and Yamazaki, D.: Hillslope Hydrology in Global Change Research and Earth System Modeling, Water Resour. Res., 55, 1737-1772, https://doi.org/10.1029/2018WR023903, 2019.

Feng, X., Thompson, S. E., Woods, R., and Porporato, A.: Quantifying Asynchronicity of Precipitation and Potential Evapotranspiration in Mediterranean Climates, Geophys. Res. Lett., 46, 14692-14701, https://doi.org/10.1029/2019GL085653, 2019.

Fleig, A. K., Tallaksen, L. M., Hisdal, H., and Demuth, S.: A global evaluation of streamflow drought characteristics, Hydrol. Earth Syst. Sci., 10, 535-552, https://doi.org/10.5194/hess-10535-2006, 2006. 
Funk, C., Peterson, P., Landsfeld, M., Pedreros, D., Verdin, J., Shukla, S., Husak, G., Rowland, J., Harrison, L., Hoell, A., and Michaelsen, J.: The climate hazards infrared precipitation with stations - a new environmental record for monitoring extremes, Sci. Data, 2, 1-21, https://doi.org/10.1038/sdata.2015.66, 2015.

Ghiggi, G., Humphrey, V., Seneviratne, S. I., and Gudmundsson, L.: GRUN: an observation-based global gridded runoff dataset from 1902 to 2014, Earth Syst. Sci. Data, 11, 1655-1674, https://doi.org/10.5194/essd-11-1655-2019, 2019.

Gleeson, T., Moosdorf, N., Hartmann, J., and van Beek, L. P. H.: A glimpse beneath earth's surface: GLobal HYdrogeology MaPS (GLHYMPS) of permeability and porosity, Geophys. Res. Lett., 41, 3891-3898, https://doi.org/10.1002/2014GL059856, 2014.

GRDC - Global Runoff Data Centre, GRDC, available at: https: //www.bafg.de/GRDC/EN/Home/homepage_node.html, last access: 24 December 2019.

Grimm, A. M.: Interannual climate variability in South America: impacts on seasonal precipitation, extreme events, and possible effects of climate change, Stoch. Env. Res. Risk A., 25, 537-554, https://doi.org/10.1007/s00477-010-0420-1, 2011.

Gudmundsson, L., Wagener, T., Tallaksen, L. M., and Engeland, K.: Evaluation of nine large-scale hydrological models with respect to the seasonal runoff climatology in Europe, Water Resour. Res., 48, W11504, https://doi.org/10.1029/2011WR010911, 2012.

Gudmundsson, L., Do, H. X., Leonard, M., and Westra, S.: The Global Streamflow Indices and Metadata Archive (GSIM) - Part 2: Quality control, time-series indices and homogeneity assessment, Earth Syst. Sci. Data, 10, 787-804, https://doi.org/10.5194/essd-10-787-2018, 2018.

Gudmundsson, L., Leonard, M., Do, H. X., Westra, S., and Seneviratne, S. I.: Observed Trends in Global Indicators of Mean and Extreme Streamflow, Geophys. Res. Lett., 46, 756-766, https://doi.org/10.1029/2018GL079725, 2019.

Gupta, H. V., Perrin, C., Blöschl, G., Montanari, A., Kumar, R., Clark, M., and Andréassian, V.: Large-sample hydrology: a need to balance depth with breadth, Hydrol. Earth Syst. Sci., 18, 463477, https://doi.org/10.5194/hess-18-463-2014, 2014.

Haddeland, I., Clark, D. B., Franssen, W., Ludwig, F., Voß, F., Arnell, N. W., and Gomes, S.: Multimodel estimate of the global terrestrial water balance: setup and first results, J. Hydrometeorol., 12, 869-884, 2011.

Hall, J., Arheimer, B., Borga, M., Brázdil, R., Claps, P., Kiss, A., Kjeldsen, T. R., Kriaučiūnienè, J., Kundzewicz, Z. W., Lang, M., Llasat, M. C., Macdonald, N., McIntyre, N., Mediero, L., Merz, B., Merz, R., Molnar, P., Montanari, A., Neuhold, C., Parajka, J., Perdigão, R. A. P., Plavcová, L., Rogger, M., Salinas, J. L., Sauquet, E., Schär, C., Szolgay, J., Viglione, A., and Blöschl, G.: Understanding flood regime changes in Europe: a state-of-the-art assessment, Hydrol. Earth Syst. Sci., 18, 27352772, https://doi.org/10.5194/hess-18-2735-2014, 2014.

Hartmann, J. and Moosdorf, N.: The new global lithological map database GLiM: A representation of rock properties at the Earth surface, Geochem. Geophy. Geosy., 13, 1-37, https://doi.org/10.1029/2012GC004370, 2012.

Haylock, M. and Nicholls, N.: Trends in extreme rainfall indices for an updated high quality data set for Australia, 1910-1998, Int. J. Climatol., 20, 1533-1541, https://doi.org/10.1002/10970088(20001115)20:13<1533::AID-JOC586>3.0.CO;2-J, 2000.
Hengl, T., Mendes de Jesus, J., Heuvelink, G. B. M., Ruiperez Gonzalez, M., Kilibarda, M., Blagotić, A., Shangguan, W., Wright, M. N., Geng, X., Bauer-Marschallinger, B., Guevara, M. A., Vargas, R., MacMillan, R. A., Batjes, N. H., Leenaars, J. G. B., Ribeiro, E., Wheeler, I., Mantel, S., and Kempen, B.: SoilGrids250m: Global gridded soil information based on machine learning, edited by: Bond-Lamberty, B., PLoS ONE, 12, e0169748, https://doi.org/10.1371/journal.pone.0169748, 2017.

Hirpa, F. A., Salamon, P., Beck, H. E., Lorini, V., Alfieri, L., Zsoter, E., and Dadson, S. J.: Calibration of the Global Flood Awareness System (GloFAS) using daily streamflow data, J. Hydrol., 566, 595-606, 2018.

Hoekstra, A. Y. and Mekonnen, M. M.: The water footprint of humanity, P. Natl. Acad. Sci. USA, 109, 3232-3237, https://doi.org/10.1073/pnas.1109936109, 2012.

Huscroft, J., Gleeson, T., Hartmann, J., and Börker, J.: Compiling and Mapping Global Permeability of the Unconsolidated and Consolidated Earth: GLobal HYdrogeology MaPS 2.0 (GLHYMPS 2.0), Geophys. Res. Lett., 45, 1897-1904, https://doi.org/10.1002/2017GL075860, 2018.

IBGE - Brazilian Institute of Geography and Statistics: Censo Agropecuário 2006, 2007.

Knoben, W. J. M., Woods, R. A., and Freer, J. E.: A Quantitative Hydrological Climate Classification Evaluated With Independent Streamflow Data, Water Resour. Res., 54, 5088-5109, https://doi.org/10.1029/2018WR022913, 2018.

Ladson, A., Brown, R., Neal, B., and Nathan, R.: A standard approach to baseflow separation using the Lyne and Hollick filter, Australian Journal of Water Resources, 17, 25-34, 2013.

Latrubesse, E. M., Arima, E. Y., Dunne, T., Park, E., Baker, V. R., d'Horta, F. M., Wight, C., Wittmann, F., Zuanon, J., Baker, P. A., Ribas, C. C., Norgaard, R. B., Filizola, N., Ansar, A., Flyvbjerg, B., and Stevaux, J. C.: Damming the rivers of the Amazon basin, Nature, 546, 363-369, https://doi.org/10.1038/nature22333, 2017.

Lehner, B.: Derivation of watershed boundaries for GRDC gauging stations based on the HydroSHEDS drainage network, Global Runoff Data Centre in the Federal Institute of Hydrology (BFG), 2012.

Lehner, B., Liermann, C. R., Revenga, C., Vörösmarty, C., Fekete, B., Crouzet, P., Döll, P., Endejan, M., Frenken, K., Magome, J., Nilsson, C., Robertson, J. C., Rödel, R., Sindorf, N., and Wisser, D.: High-resolution mapping of the world's reservoirs and dams for sustainable river-flow management, Front. Ecol. Environ., 9, 494-502, https://doi.org/10.1890/100125, 2011.

Leite, C. C., Costa, M. H., Soares-Filho, B. S., and de Barros Viana Hissa, L.: Historical land use change and associated carbon emissions in Brazil from 1940 to 1995, Global Biogeochem. Cy., 26, 1-13, https://doi.org/10.1029/2011GB004133, 2012.

Levy, M. C., Lopes, A. V., Cohn, A., Larsen, L. G., and Thompson, S. E.: Land Use Change Increases Streamflow Across the Arc of Deforestation in Brazil, Geophys. Res. Lett., 45, 3520-3530, https://doi.org/10.1002/2017GL076526, 2018.

Lima, C. H. R., AghaKouchak, A., and Lall, U.: Classification of mechanisms, climatic context, areal scaling, and synchronization of floods: the hydroclimatology of floods in the Upper Paraná River basin, Brazil, Earth Syst. Dynam., 8, 1071-1091, https://doi.org/10.5194/esd-8-1071-2017, 2017. 
Linke, S., Lehner, B., Ouellet Dallaire, C., Ariwi, J., Grill, G., Anand, M., Beames, P., Burchard-Levine, V., Maxwell, S., Moidu, H., Tan, F., and Thieme, M.: Global hydro-environmental sub-basin and river reach characteristics at high spatial resolution, Sci. Data, 6, 1-15, https://doi.org/10.1038/s41597-0190300-6, 2019.

Luke, A., Vrugt, J. A., AghaKouchak, A., Matthew, R., and Sanders, B. F.: Predicting nonstationary flood frequencies: Evidence supports an updated stationarity thesis in the United States, Water Resour. Res., 53, 5469-5494, https://doi.org/10.1002/2016WR019676, 2017.

Marengo, J. A. and Espinoza, J. C.: Extreme seasonal droughts and floods in Amazonia: causes, trends and impacts, Int. J. Climatol., 36, 1033-1050, https://doi.org/10.1002/joc.4420, 2016.

Martens, B., Miralles, D. G., Lievens, H., van der Schalie, R., de Jeu, R. A. M., Fernández-Prieto, D., Beck, H. E., Dorigo, W. A., and Verhoest, N. E. C.: GLEAM v3: satellite-based land evaporation and root-zone soil moisture, Geosci. Model Dev., 10, 1903 1925, https://doi.org/10.5194/gmd-10-1903-2017, 2017.

Martinez, J. A. and Dominguez, F.: Sources of Atmospheric Moisture for the La Plata River Basin, J. Climate, 27, 6737-6753, https://doi.org/10.1175/JCLI-D-14-00022.1, 2014.

McMillan, H., Westerberg, I., and Branger, F.: Five guidelines for selecting hydrological signatures, Hydrol. Process., 31, 47574761, https://doi.org/10.1002/hyp.11300, 2017.

Melo, D. D. C. D., Scanlon, B. R., Zhang, Z., Wendland, E., and Yin, L.: Reservoir storage and hydrologic responses to droughts in the Paraná River basin, south-eastern Brazil, Hydrol. Earth Syst. Sci., 20, 4673-4688, https://doi.org/10.5194/hess-20-46732016, 2016.

Merz, B., Vorogushyn, S., Uhlemann, S., Delgado, J., and Hundecha, Y.: HESS Opinions "More efforts and scientific rigour are needed to attribute trends in flood time series", Hydrol. Earth Syst. Sci., 16, 1379-1387, https://doi.org/10.5194/hess-16-13792012, 2012.

Milliman, J. D., Farnsworth, K. L., Jones, P. D., Xu, K. H., and Smith, L. C.: Climatic and anthropogenic factors affecting river discharge to the global ocean, 1951-2000, Global Planet. Change, 62, 187-194, https://doi.org/10.1016/j.gloplacha.2008.03.001, 2008.

Miralles, D. G., Holmes, T. R. H., De Jeu, R. A. M., Gash, J. H., Meesters, A. G. C. A., and Dolman, A. J.: Global land-surface evaporation estimated from satellite-based observations, Hydrol. Earth Syst. Sci., 15, 453-469, https://doi.org/10.5194/hess-15453-2011, 2011.

Montanari, A.: What do we mean by "uncertainty"? The need for a consistent wording about uncertainty assessment in hydrology, Hydrol. Process., 21, 841-845, https://doi.org/10.1002/hyp.6623, 2007.

Montanari, A., Young, G., Savenije, H. H. G., Hughes, D., Wagener, T., Ren, L. L., Koutsoyiannis, D., Cudennec, C., Toth, E., Grimaldi, S., Blöschl, G., Sivapalan, M., Beven, K., Gupta, H., Hipsey, M., Schaefli, B., Arheimer, B., Boegh, E., Schymanski, S. J., Di Baldassarre, G., Yu, B., Hubert, P., Huang, Y., Schumann, A., Post, D. A., Srinivasan, V., Harman, C., Thompson, S., Rogger, M., Viglione, A., McMillan, H., Characklis, G., Pang, Z., and Belyaev, V.: "Panta Rhei - Everything Flows": Change in hydrology and society - The IAHS Sci- entific Decade 2013-2022, Hydrolog. Sci. J., 58, 1256-1275, https://doi.org/10.1080/02626667.2013.809088, 2013.

Müller Schmied, H., Eisner, S., Franz, D., Wattenbach, M., Portmann, F. T., Flörke, M., and Döll, P.: Sensitivity of simulated global-scale freshwater fluxes and storages to input data, hydrological model structure, human water use and calibration, Hydrol. Earth Syst. Sci., 18, 3511-3538, https://doi.org/10.5194/hess-18-3511-2014, 2014.

Newman, A. J., Clark, M. P., Sampson, K., Wood, A., Hay, L. E., Bock, A., Viger, R. J., Blodgett, D., Brekke, L., Arnold, J. R., Hopson, T., and Duan, Q.: Development of a large-sample watershed-scale hydrometeorological data set for the contiguous USA: data set characteristics and assessment of regional variability in hydrologic model performance, Hydrol. Earth Syst. Sci., 19, 209-223, https://doi.org/10.5194/hess-19-209-2015, 2015.

NOAA: CPC Global Temperature, available at: https://www.esrl. noaa.gov/psd/ (last access 15 June 2019), 2019a.

NOAA: CPC Global Unified Precipitation, available at: https:// www.esrl.noaa.gov/psd/ (last access: 15 June 2019), 2019b.

Olden, J. D. and Poff, N. L.: Redundancy and the choice of hydrologic indices for characterizing streamflow regimes, River Res. Appl., 19, 101-121, https://doi.org/10.1002/rra.700, 2003.

ONS - National Electrical System Operator: SIGEL - Sistema Geográfico de Informações do Sistema Elétrico, available at: https://sigel.aneel.gov.br/, last access: 10 December 2019.

Paiva, R. C. D., Buarque, D. C., Collischonn, W., Bonnet, M.P., Frappart, F., Calmant, S., and Bulhões Mendes, C. A.: Large-scale hydrologic and hydrodynamic modeling of the Amazon River basin, Water Resour. Res., 49, 1226-1243, https://doi.org/10.1002/wrcr.20067, 2013.

Pasquini, A. I. and Depetris, P. J.: Discharge trends and flow dynamics of South American rivers draining the southern Atlantic seaboard: An overview, J. Hydrol., 333, 385-399, https://doi.org/10.1016/j.jhydrol.2006.09.005, 2007.

Pfister, L. and Kirchner, J. W.: Debates-Hypothesis testing in hydrology: Theory and practice, Water Resour. Res., 53, 1792 1798, https://doi.org/10.1002/2016WR020116, 2017.

Raia, A. and Cavalcanti, I. F. A.: The Life Cycle of the South American Monsoon System, J. Climate, 21, 6227-6246, https://doi.org/10.1175/2008JCLI2249.1, 2008.

Salio, P., Nicolini, M., and Zipser, E. J.: Mesoscale convective systems over southeastern South America and their relationship with the South American low-level jet, Mon. Weather Rev., 135, 1290-1309, 2007.

Sankarasubramanian, A., Vogel, R. M., and Limbrunner, J. F.: Climate elasticity of streamflow in the United States, Water Resour. Res., 37, 1771-1781, https://doi.org/10.1029/2000WR900330, 2001.

Sawicz, K., Wagener, T., Sivapalan, M., Troch, P. A., and Carrillo, G.: Catchment classification: empirical analysis of hydrologic similarity based on catchment function in the eastern USA, Hydrol. Earth Syst. Sci., 15, 2895-2911, https://doi.org/10.5194/hess-15-2895-2011, 2011.

Sawicz, K. A., Kelleher, C., Wagener, T., Troch, P., Sivapalan, M., and Carrillo, G.: Characterizing hydrologic change through catchment classification, Hydrol. Earth Syst. Sci., 18, 273-285, https://doi.org/10.5194/hess-18-273-2014, 2014.

Schewe, J., Heinke, J., Gerten, D., Haddeland, I., Arnell, N. W., Clark, D. B., and Gosling, S. N.: Multimodel assessment of wa- 
ter scarcity under climate change, P. Natl. Acad. Sci. USA, 111, 3245-3250, 2014.

Schobbenhaus, C., Gonçalves, J., Santos, J., Abram, M., Leão Neto, R., Matos, G., Vidotti, R., Ramos, M., and de Jesus, J.: Carta geológica do Brasil ao milionésimo: Sistema de Informações Heográficas, CPRM - Serviço Geológico do Brasil, Brasília, 2004.

Seager, R., Naik, N., Baethgen, W., Robertson, A., Kushnir, Y., Nakamura, J., and Jurburg, S.: Tropical Oceanic Causes of Interannual to Multidecadal Precipitation Variability in Southeast South America over the Past Century, J. Climate, 23, 5517-5539, https://doi.org/10.1175/2010JCLI3578.1, 2010.

Shangguan, W., Hengl, T., Mendes de Jesus, J., Yuan, H., and Dai, Y.: Mapping the global depth to bedrock for land surface modeling, J. Adv. Model. Earth Sy., 9, 65-88, https://doi.org/10.1002/2016MS000686, 2017.

Shen, X., Anagnostou, E. N., Mei, Y., and Hong, Y.: A global distributed basin morphometric dataset, Sci. Data, 4, 160124, https://doi.org/10.1038/sdata.2016.124, 2017.

Singh, R., Archfield, S. A., and Wagener, T.: Identifying dominant controls on hydrologic parameter transfer from gauged to ungauged catchments - A comparative hydrology approach, J. Hydrol., 517, 985-996, https://doi.org/10.1016/j.jhydrol.2014.06.030, 2014.

Siqueira, V. A., Paiva, R. C. D., Fleischmann, A. S., Fan, F. M., Ruhoff, A. L., Pontes, P. R. M., Paris, A., Calmant, S., and Collischonn, W.: Toward continental hydrologic-hydrodynamic modeling in South America, Hydrol. Earth Syst. Sci., 22, 48154842, https://doi.org/10.5194/hess-22-4815-2018, 2018.

Slater, L. J., Singer, M. B., and Kirchner, J. W.: Hydrologic versus geomorphic drivers of trends in flood hazard, Geophys. Res. Lett., 42, 370-376, https://doi.org/10.1002/2014GL062482, 2015.

Smakhtin, V. U.: Low flow hydrology: a review, J. Hydrol., 240, 147-186, https://doi.org/10.1016/S0022-1694(00)00340-1, 2001.

Song, X.-P., Hansen, M. C., Stehman, S. V., Potapov, P. V., Tyukavina, A., Vermote, E. F., and Townshend, J. R.: Global land change from 1982 to 2016, Nature, 560, 639-643, https://doi.org/10.1038/s41586-018-0411-9, 2018.

Sun, Q., Miao, C., Duan, Q., Ashouri, H., Sorooshian, S., and Hsu, K.: A Review of Global Precipitation Data Sets: Data Sources, Estimation, and Intercomparisons, Rev. Geophys., 56, 79-107, https://doi.org/10.1002/2017RG000574, 2018.

Tedeschi, R. G., Cavalcanti, I. F. A., and Grimm, A. M.: Influences of two types of ENSO on South American precipitation, Int. J. Climatol., 33, 1382-1400, https://doi.org/10.1002/joc.3519, 2013.

Tomasella, J., Borma, L. S., Marengo, J. A., Rodriguez, D. A., Cuartas, L. A., A. Nobre, C., and Prado, M. C. R.: The droughts of 1996-1997 and 2004-2005 in Amazonia: hydrological response in the river main-stem, Hydrol. Process., 25, 1228-1242, https://doi.org/10.1002/hyp.7889, 2011.

Van Lanen, H. A. J., Wanders, N., Tallaksen, L. M., and Van Loon, A. F.: Hydrological drought across the world: impact of climate and physical catchment structure, Hydrol. Earth Syst. Sci., 17, 1715-1732, https://doi.org/10.5194/hess-17-1715-2013, 2013.
Van Loon, A. F.: Hydrological drought explained, WIREs Water, 2, 359-392, https://doi.org/10.1002/wat2.1085, 2015.

Veldkamp, T. I. E., Zhao, F., Ward, P. J., De Moel, H., Aerts, J. C., Schmied, H. M., and Satoh, Y.: Human impact parameterizations in global hydrological models improve estimates of monthly discharges and hydrological extremes: a multi-model validation study, Environ. Res. Lett., 13, 055008, https://doi.org/10.1088/1748-9326/aab96f, 2018.

Villarini, G.: On the seasonality of flooding across the continental United States, Adv. Water Resour., 87, 80-91, https://doi.org/10.1016/j.advwatres.2015.11.009, 2016.

Wada, Y., Wisser, D., and Bierkens, M. F. P.: Global modeling of withdrawal, allocation and consumptive use of surface water and groundwater resources, Earth Syst. Dynam., 5, 15-40, https://doi.org/10.5194/esd-5-15-2014, 2014.

Westerberg, I. K. and McMillan, H. K.: Uncertainty in hydrological signatures, Hydrol. Earth Syst. Sci., 19, 3951-3968, https://doi.org/10.5194/hess-19-3951-2015, 2015.

Wohl, E., Barros, A., Brunsell, N., Chappell, N. A., Coe, M., Giambelluca, T., Goldsmith, S., Harmon, R., Hendrickx, J. M. H., Juvik, J., McDonnell, J., and Ogden, F.: The hydrology of the humid tropics, Nat. Clim. Change, 2, 655-662, https://doi.org/10.1038/nclimate1556, 2012.

Woldemeskel, F. and Sharma, A.: Should flood regimes change in a warming climate? The role of antecedent moisture conditions, Geophys. Res. Lett., 43, 7556-7563, https://doi.org/10.1002/2016GL069448, 2016.

Woods, R. A.: Analytical model of seasonal climate impacts on snow hydrology: Continuous snowpacks, Adv. Water Resour., 32, 1465-1481, https://doi.org/10.1016/j.advwatres.2009.06.011, 2009.

Wongchuig, S. C., de Paiva, R. C. D., Siqueira, V., and Collischonn, W.: Hydrological reanalysis across the 20th century: A case study of the Amazon Basin, J. Hydrol., 570, 755-773, 2019.

Xavier, A. C., King, C. W., and Scanlon, B. R.: Daily gridded meteorological variables in Brazil (1980-2013), Int. J. Climatol., 36, 2644-2659, https://doi.org/10.1002/joc.4518, 2016.

Yadav, M., Wagener, T., and Gupta, H.: Regionalization of constraints on expected watershed response behavior for improved predictions in ungauged basins, Adv. Water Resour., 30, 17561774, https://doi.org/10.1016/j.advwatres.2007.01.005, 2007.

Yokoo, Y. and Sivapalan, M.: Towards reconstruction of the flow duration curve: development of a conceptual framework with a physical basis, Hydrol. Earth Syst. Sci., 15, 2805-2819, https://doi.org/10.5194/hess-15-2805-2011, 2011.

Zhao, F., Veldkamp, T. I., Frieler, K., Schewe, J., Ostberg, S., Willner, S., and Leng, G.: The critical role of the routing scheme in simulating peak river discharge in global hydrological models, Environ. Res. Lett., 12, 075003, https://doi.org/10.1088/17489326/aa7250, 2017.

Zscheischler, J., Westra, S., van den Hurk, B. J. J. M., Seneviratne, S. I., Ward, P. J., Pitman, A., AghaKouchak, A., Bresch, D. N., Leonard, M., Wahl, T., and Zhang, X.: Future climate risk from compound events, Nat. Clim. Change, 8, 469-477, https://doi.org/10.1038/s41558-018-0156-3, 2018. 